\title{
CASCADING OVER THE CONTINENTAL SLOPE OF WATER FROM THE CELTIC SEA ${ }^{1}$
}

\author{
By L. H. N. Cooper, D.Sc. \\ Chemist at the Plymouth Laboratory \\ and David Vaux, B.Sc. \\ Fisheries Laboratories, Lowestoft
}

(Text-figs. I-I4)

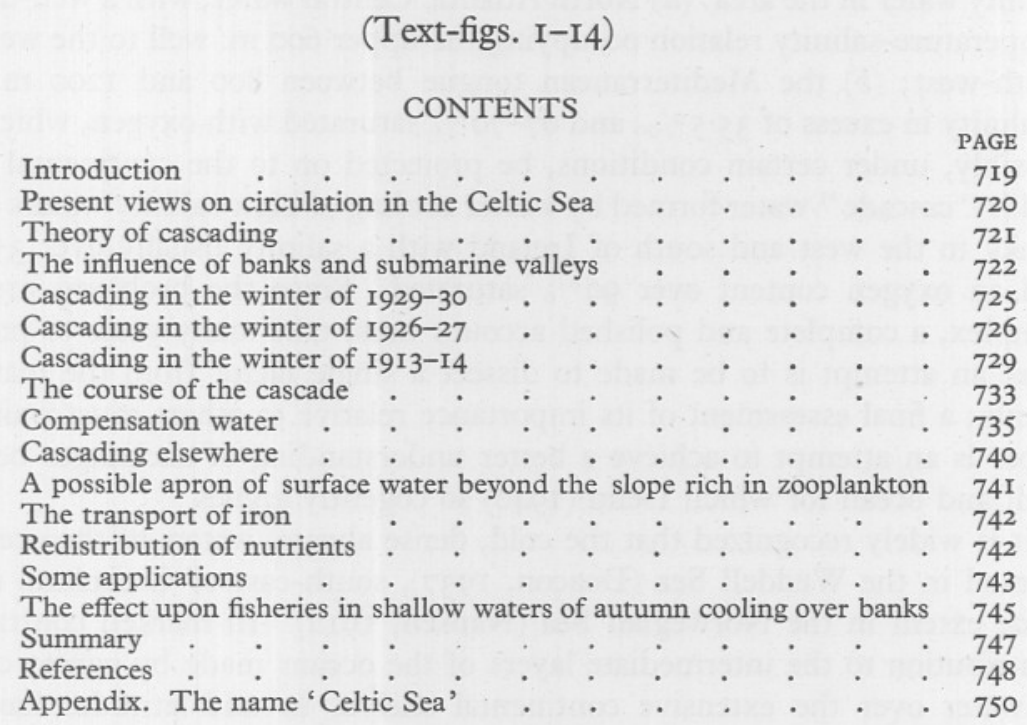

This paper is an essay on the theme that water, cooled in winter, will sink and flow downhill over the sea floor. It will be shown that in some winters water in the Celtic Sea to the south of Ireland became heavy enough to flow to the edge of the continental shelf and there to sink to a depth of several hundred metres. It will be shown, further, that in one year it actually did so. A theory of this phenomenon, termed 'cascading', has been developed, and implications capable of test by observation are discussed.

\section{INTRODUCTION}

A better understanding of the oceanography of the English Channel requires a fuller knowledge of the nature of the movements of water within the Celtic Sea, and of the water which enters or leaves the ocean over the Continental Slope. This need has been strengthened by the demand from the fishery naturalists for a statement of the physical and chemical conditions in the Celtic

${ }^{1}$ For a definition of the name 'Celtic Sea', see Appendix, p. 750 . 
Sea during the mackerel investigations of 1937-39. In that area, and in the English Channel, attempts to correlate the distribution of plants, animals and chemical nutrients on the one hand with salinity and currents deduced from salinity and temperature diagrams on the other have been singularly barren. No correlation such as that between the winter maximum phosphate and the distribution of young fish has ever emerged.

This negative result has become so definite that it can have but one meaning; the presence of waters with similar salinities but very different physical and biological histories. Comparative study of the ocean water to the west and south-west seems essential. It would appear that there are three types of highsalinity water in the area: (a) North Atlantic Central water, with a well-defined temperature-salinity relation occupying the upper $600 \mathrm{~m}$. well to the west and south-west; (b) the Mediterranean tongue between 800 and I200 m. with a salinity in excess of $35.5 \%$ and $67-70 \%$ saturated with oxygen, which may possibly, under certain conditions, be projected on to the continental shelf; and $(c)$ "cascade "1 water formed by winter cooling of high-salinity waters on the banks to the west and south of Ireland with a salinity úsually over $35.4 \%$ and an oxygen content over $90 \%$ saturated. Since the problems are very complex, a complete and polished account must take many years to prepare. Here an attempt is to be made to dissect a single factor from the matrix of events; a final assessment of its importance relative to others must wait. The paper is an attempt to achieve a better understanding of exchanges between shelf and ocean for which Iselin (I940) so cogently argues.

It is widely recognized that the cold, dense abyssal waters of the ocean are formed in the Weddell Sea (Deacon, 1937), south-east of Greenland and to some extent in the Norwegian Sea (Nansen, 19I2). In marked contrast the contribution to the intermediate layers of the oceans made by winter cooling of water over the extensive continental shelves in mid-latitudes has been neglected. None the less, the effect upon the oceans on the one hand and upon the productivity of fishing grounds on the other may well be profound. In this paper, therefore, the effect upon circulation in the Celtic Sea and the adjacent ocean of the increase in density of shelf water south of Ireland in winter is to be discussed.

\section{Present Views of Circulation in the Celtic Sea}

The account given by Matthews (I9I4) remains unchallenged. In general, a current of salt warm water enters the English Channel from a south-westerly direction and in part turns northwards and north-westwards to escape into the Irish Channel. Part again follows the south coast of Ireland and, on occasion, there may be a centre to the cyclonic eddy in about $51^{\circ} \mathrm{N}$., $6^{\circ} 40^{\prime} \mathrm{W}$. It may be said at once that nothing here to be presented is in conflict with Matthews' account of a cyclonic circulation.

\footnotetext{
1 A very descriptive term due to $\mathrm{Mr} \mathrm{G}$. A. Steven.
} 


\section{THEORY OF CASCADING ${ }^{1}$}

In autumn and winter heat is lost from the surface of the sea mainly by radiation and evaporation. To a first approximation the extent to which this happens is directly dependent on the area of sea surface.

Let us consider two positions in winter, A and B (Fig. I), having the same initial salinity, temperature and density, and exposed to similar meteorological conditions; at B the water is twice as deep as at A. If at B purely vertical mixing is sufficient to equalize the temperature there, the fall in temperature will be only half as great as at A. Although at both positions the loss of heat through the surface is much the same, at B, it would be distributed through twice the depth as at A. Since at A the water has become not only colder but heavier, it will tend to cascade or flow downhill along the bottom from A to B.

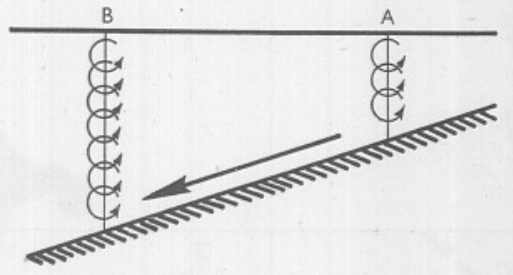

Fig. I. The basis of cascading

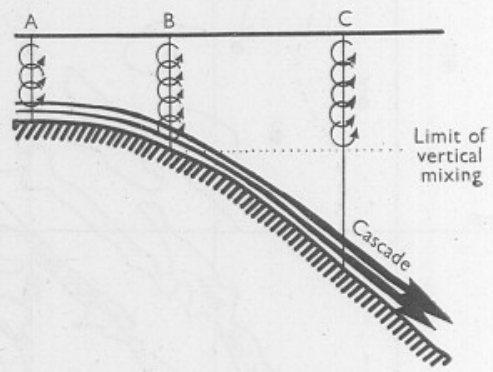

Fig. 2. Cascading over the Continental Slope.

Although in an enclosed tank the result would be an isothermal and completely uniform body of water in which it would be impossible to separate downhill movement from purely vertical mixing, in nature this need not be so.

Let us consider the edge of the continental shelf above the continental slope (Fig. 2). At the inshore and shallower station A the water should be cooled to a greater extent than at the deeper station B. In consequence a bottom or cascade current should become established from A to B. All the time straightforward vertical mixing due to wind and cooling in situ will be occurring down to the depth of maximum vertical mixing. The combined result should be a current setting from A through B with its greatest strength near the bottom. When the bottom current approaches the edge of the slope there should come a depth to which vertical mixing could no longer reach as indicated by the dotted line near station C. It would, however, continue to cascade as a heavy

\footnotetext{
${ }^{1}$ After we had received proofs of the present paper, we saw, unfortunately, for the first time, a paper by Fridtjof Nansen (1913), describing the effect of winter cooling over the Rockall Bank and the descent of the resulting heavy water over the adjacent slope. Nansen has given a complete description of cascading there. Since the importance of his concept, as applied in temperate latitudes would seem not to have been widely recognized and accepted, a completely independent derivation and application in another area, accompanied by further deductions, may not prove unwelcome. Accordingly no alteration has been made in the present text.
} 
relatively cold blanket of water until it should reach such a depth on the wall of the slope as would correspond to the density of the neighbouring ocean water. In a cold winter this depth would evidently lie deeper than in a mild one.

Since the cascaded water has to be replaced, somewhere or other compensation water must break in, most probably from the ocean. This theme will be more fully discussed on pp. 735-40.

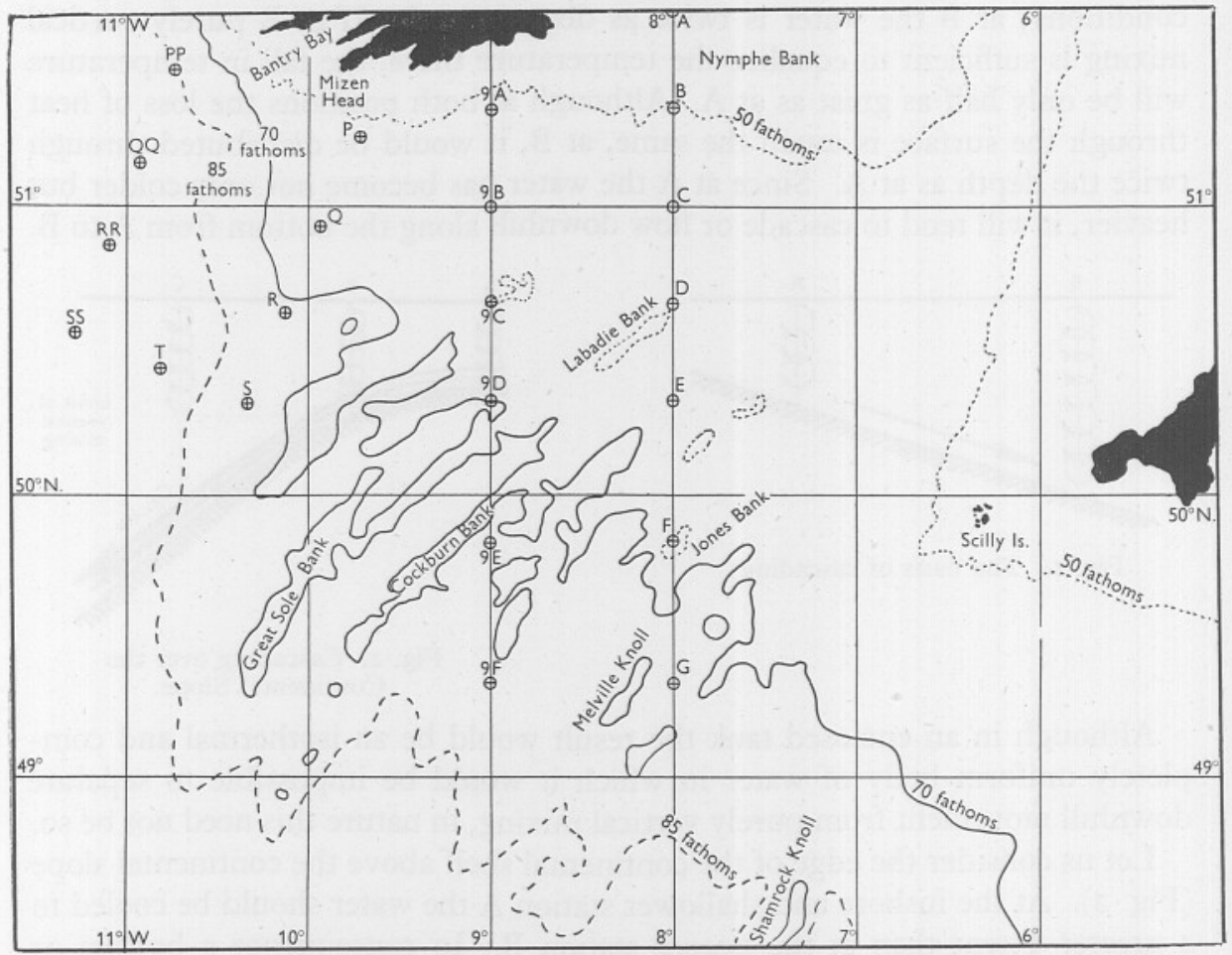

Fig. 3. Submerged 'river valleys' as revealed by the 70 and $85 \mathrm{fm}$. contours, and of banks as revealed by the $50 \mathrm{fm}$. contour; also positions of standard Irish Stations worked between I92I and 1933 .

\section{The INFLUENCE of Banks and SubMarine Valleys}

It is necessary here to develop another concept needed later. Contouring the chart in the neighbourhood of the Great Sole and Cockburn Banks $\left(49^{\circ} 45^{\prime} \mathrm{N}\right.$., $9^{\circ} 30^{\prime} \mathrm{W}$.) reveals a very striking picture of a submarine peneplain ${ }^{1}$ at $65 \mathrm{fm}$. (I20 m.), dissected by troughs about $15-20 \mathrm{fm}$. deep like a series of submerged river valleys (Le Danois, I938, fig. 10), the direction of which is south-west to north-east (see Fig. 3).

1 A 'peneplain' is a gently rolling lowland produced after long-continued denudation of a land mass. The floor of the Celtic Sea conforms closely to this definition except that it is submarine. The term is graphic and more suitable than 'shelf' or 'terrace' for the arguments to be developed. 
It may be remarked that the depth of $120 \mathrm{~m}$. (400 ft. or $65 \mathrm{fm}$.) figures frequently in discussions of the maximum withdrawal of the sea during the Pleistocene Ice Ages (inter alia, Farrington, I945; Flint, I947).

The soundings on the charts, which are not dense enough to give any idea of the vertical sections across the troughs, do not require any gradient steeper than I in roo. However, it would seem that during the period of low sea-level when these troughs were probably cut, the climate was glacial and the rivers concerned drained the whole of northern France, southern and western England and Wales, eastern Ireland, and perhaps even the Clyde Basin. They should have been strongly seasonal with little flow in winter and very heavy erosive spates during the summer melting of the ice; such may well have led to deep
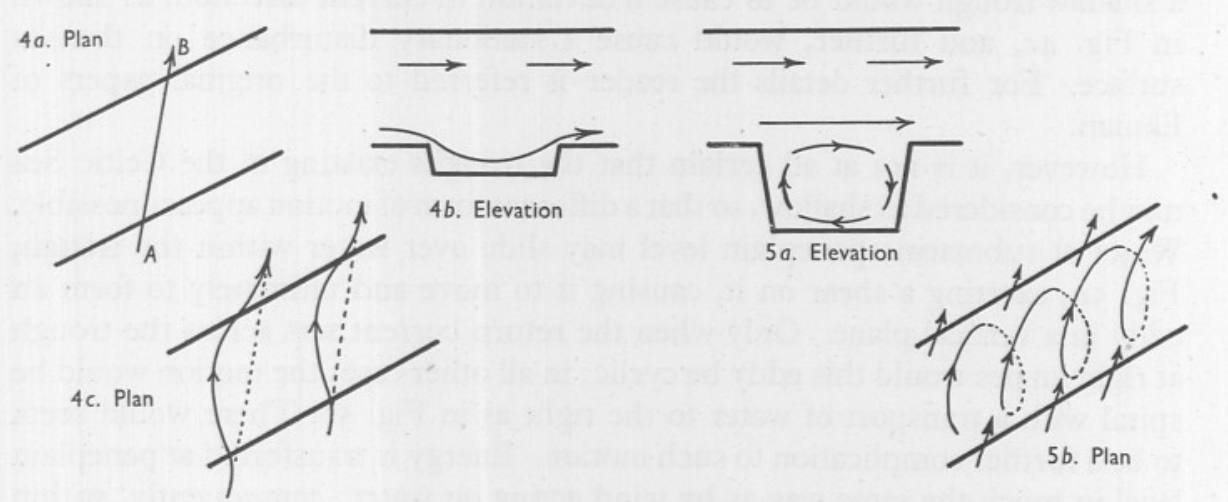

Figs. 4 and 5. Diagrams illustrating possible water movements above valleys or troughs dissecting a submarine peneplain. Fig. $4 a, b$ and $c$ : motion above shallow troughs; Fig. $5 a$, $b$ : over and in deep troughs.

entrenchment between steep banks when carved in consolidated rock. However, 60 miles to the south, Bullard \& Gaskell (I94I) have made two seismic soundings of the sea floor. They believe that unconsolidated sediments at $48^{\circ} 54^{\prime}$ N., $9^{\circ} \mathrm{Io}^{\prime} \mathrm{W}$. extend to at least $1090 \mathrm{~m}$., and at $48^{\circ} 45^{\prime} \mathrm{N} ., 9^{\circ} 48^{\prime} \mathrm{W}$. to $2470 \mathrm{~m}$. below the sea floor. In such unconsolidated sediments glacial rivers would have cut down exceedingly quickly; with the return of the sea the banks would have been destroyed and the river beds filled in just as easily. Only an echo-sounding survey can show quickly whether any steep banks now remain. It may then be possible to say how far such submarine valleys may canalize bottom currents in this area in a south-westerly-north-easterly direction and impede currents whose direction is at right angles to the axis of the valleys.

We can investigate the situation theoretically by a simplification of the factors involved. Consider a parallel-sided trough in an otherwise level submarine peneplain, and let a current set across the trough at an angle to the longitudinal axis of the trough. In diagram Fig. $4 a, A B$ represents the direction of the current at peneplain level. Such a current may be produced by tidal 
forces, density differences between adjacent masses of water, or wind. If the current be wind-produced, the direction of current at peneplain level would, according to Ekman's (I905) theory of wind drift, be different from that at the surface. However, if the current at peneplain level flows in a given direction $A B$, it is of no importance to the theory which follows whether the water above flows all in one direction or according to an Ekman spiral.

In order to continue the investigation, it appears necessary to differentiate between two possible forms of motion. If the water sinks into the trough and rises at the opposite side, as Fig. $4 b$, the theory developed by Ekman (I923, I927, I932), and summarized by Sverdrup (in Sverdrup, Johnson \& Fleming, I942, pp. 466-9), would seem to apply. In the Celtic Sea the influence of a shallow trough would be to cause a deviation in current direction, as shown in Fig. $4 c$, and further, would cause a stationary disturbance on the sea surface. For further details the reader is referred to the original papers of Ekman.

However, it is not at all certain that the troughs existing in the Celtic Sea may be considered as shallow, so that a different form of motion appears possible. Water at submarine peneplain level may slide over water within the trough, Fig. $5 a$, exerting a shear on it, causing it to move and ultimately to form an eddy in a vertical plane. Only when the return current sets across the trough at right angles would this eddy be cyclic; in all other cases the motion would be spiral with a transport of water to the right as in Fig. $5 b$. There would seem to be a further complication to such motion. Energy is transferred at peneplain level in much the same way as by wind acting on water; consequently, within the trough a form of Ekman spiral, much modified by turbulence, should be set up.

When conditions along the trough are not uniform, yet another possibility may arise. At a point where the current within the trough is weak, the water approaching its edge could turn back on itself at the same level, producing something akin to a 'rip current' (see Shepard, Emery \& La Fond (I94I) for a description of surface rip currents).

A theoretical solution at this stage seems impossible, but it appears from the survey outlined above that turbulence from bottom to surface should be great, and that energy is dissipated, causing diminution in the original currents. This turbulence may redistribute nutrients throughout the water column and, providing it is not excessive, favour their more efficient usage by plants.

Tentative inferences for the Great Sole-Cockburn Bank Area which can be substantiated only by fresh observations on the spot, are: (I) that currents, however caused, may tend to conform to the direction of the submarine valleys; (2) that in summer the thermocline should be more weakly developed than in neighbouring undissected regions of the shelf having the same depth and exposure to ocean swell; (3) that a useful stock of inorganic nutrients, including iron, may be maintained in the upper photosynthetic zone right through the 
summer; and (4) that the falling off in late spring in production of phytoplankton, so characteristic of the waters near Plymouth, where the thermocline may develop very strongly, may be much less marked.

\section{CASCADING IN THE WINTER OF I929-30}

Within the $100 \mathrm{fm}$. contour of the Celtic Sea extensive salinity and temperature observations, collected mostly between I92I and I933 by the Irish Fisheries Service under the direction of the late Mr G. P. Farran, are available, but for the waters bathing the continental slope there are far fewer. All the observations have been taken from the 'Rapports Atlantiques' and the 'Bulletins Hydrographiques' published annually by the International Council for the Exploration of the Sea, Copenhagen. Satisfactory proof of cascading is difficult to adduce on the basis of salinity and temperature alone and to clinch the argument the measurements of oxygen and $\mathrm{pH}$ made on board Armauer Hansen in I9I4 have been invaluable.

Other factors being similar, cascading should have developed most strongly in those winters in which air temperatures were low. To assess meteorological cooling of the sea, some way of integrating departures of temperature from the mean during the whole winter is needed; not an easy task. As a lead, air temperatures in February at Valencia (Cahirciveen), Scilly and Guernsey were examined. Of the years I92I-33, I930 was the coldest at Valencia (below average by $2.7^{\circ} \mathrm{C}$.) and at Scilly (by $2.3^{\circ} \mathrm{C}$.); Guernsey was somewhat cold but only below average by $\mathrm{I} \cdot 3^{\circ} \mathrm{C}$. By contrast in 1929 , whereas Valencia and Scilly were average, the Guernsey mean February temperature was $2 \cdot 7^{\circ} \mathrm{C}$. below average. This was reflected in the discrepancy in temperature difference between the Hurd Deep, north-east of Guernsey, and the waters south-west of Ireland (Cooper, in Steven, 1949, Appendix). In 1924, and again in 1932, the whole area was below average by $0 \cdot 9-\mathrm{I} \cdot 2^{\circ}$ and $\mathrm{I} \cdot 4^{\circ} \mathrm{C}$. respectively. The year 1927 was average, whilst 1926 and 1928 were well above average, and consequently unattractive for our present purpose.

On this evidence the winter of 1930 appeared most likely to yield results. In mid-February of that year the density, $\sigma_{t}$, of bottom water in the northern Celtic Sea along the meridian of $8^{\circ} \mathrm{W}$. was around 27.3 and along that of $9^{\circ} \mathrm{W} .27 .4$. West of Co. Mayo, 200 miles to the north and 3 months earlier, H.M.S. Ormonde had found that water having $\sigma_{t} 27 \cdot 3-27 \cdot 4$ lay between depths of 400 and $700 \mathrm{~m}$. (Fig. 6). If one may correlate observations made so far apart, it would seem that the shelf water in the northern Celtic Sea was heavy enough to sink over the slope to between 400 and $700 \mathrm{~m}$. Unfortunately, there is yet another consideration which makes it unwise to base the theory of cascading on events in 1930.

Wind must always be a force, often a very powerful force, able to initiate and maintain currents. If in any winter the distribution and power of winds were such as to set up a current system in the same sense as that demanded by 
cascading, then evidence from that winter ought not to be adduced in favour of cascading. For 2I out of the 28 days of February 1930, winds blew from the north-eastern quadrant and on 16 of those days the force exceeded three on the Beaufort scale. Such winds would, of themselves, provide a likely explanation of currents towards the west and south-west. This issue is discussed again later.

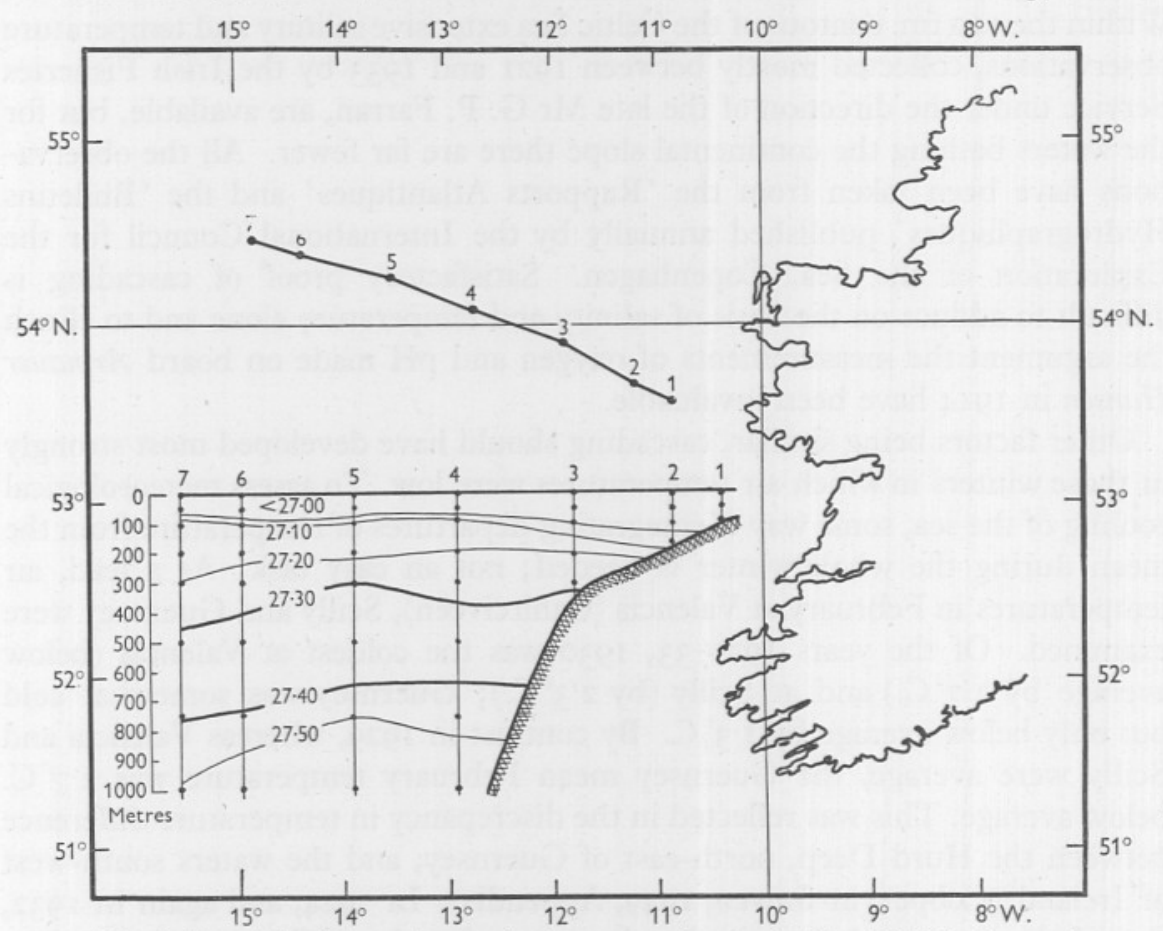

Fig. 6. Densities (shown in inset) along a section worked by H.M.S. Ormonde off the west coast of Ireland, 22-25 October I929.

\section{CASCADING IN THE WINTER OF I926-27}

Owing to the unsuitability of the winter of $1929-30$, attention was switched to that of 1926-27. In this year the February air temperature at Valencia and Scilly equalled the average for the I3 years, I92I-33. With a very full network of Irish, English and French stations all worked between I 5 and 20 February 1927, a simultaneous and revealing picture of the whole shelf is possible.

Temperatures were lowest $\left(<8^{\circ} \mathrm{C}\right.$. $)$ in the Irish Sea and the eastern end of the English Channel, and increased to the west and south-west. Within the Celtic Sea the coldest water $\left(<9^{\circ} \mathrm{C}\right.$. $)$ lay over the Nymphe Bank. The conditions are, however, best understood from the distribution of surface density. In the Irish Sea the low temperature was more than outweighed by the low salinity $(34.3-34.4 \%$ on the Holyhead-Kingstown line). In consequence, density $\left(\sigma_{t}\right)$ at the surface (Fig. 7) increased towards the south-west, exceeding 
$27 \cdot 30$ on the Nymphe Bank at the eighth meridian and reaching $27 \cdot 40$ at the ninth as in 1930 .

The English Channel showed quite a different pattern, since a lane of high density $(>27 \cdot 30)$ stretched throughout its entire length from the Southern Bight of the North Sea to the Celtic Sea. North of $49^{\circ} \mathrm{N}$. in the latter, the distribution of surface density well represents that of the deeper water as shown by the three vertical sections (Fig. 8) whose position is shown on Fig. 7; south of $49^{\circ} \mathrm{N}$. the distribution of density was utterly different and has to be discussed later (pp. 737-9). Even so, to the north there was more than I0,000 square miles of sea with density exceeding $\sigma_{t} 27 \cdot 30$, potentially

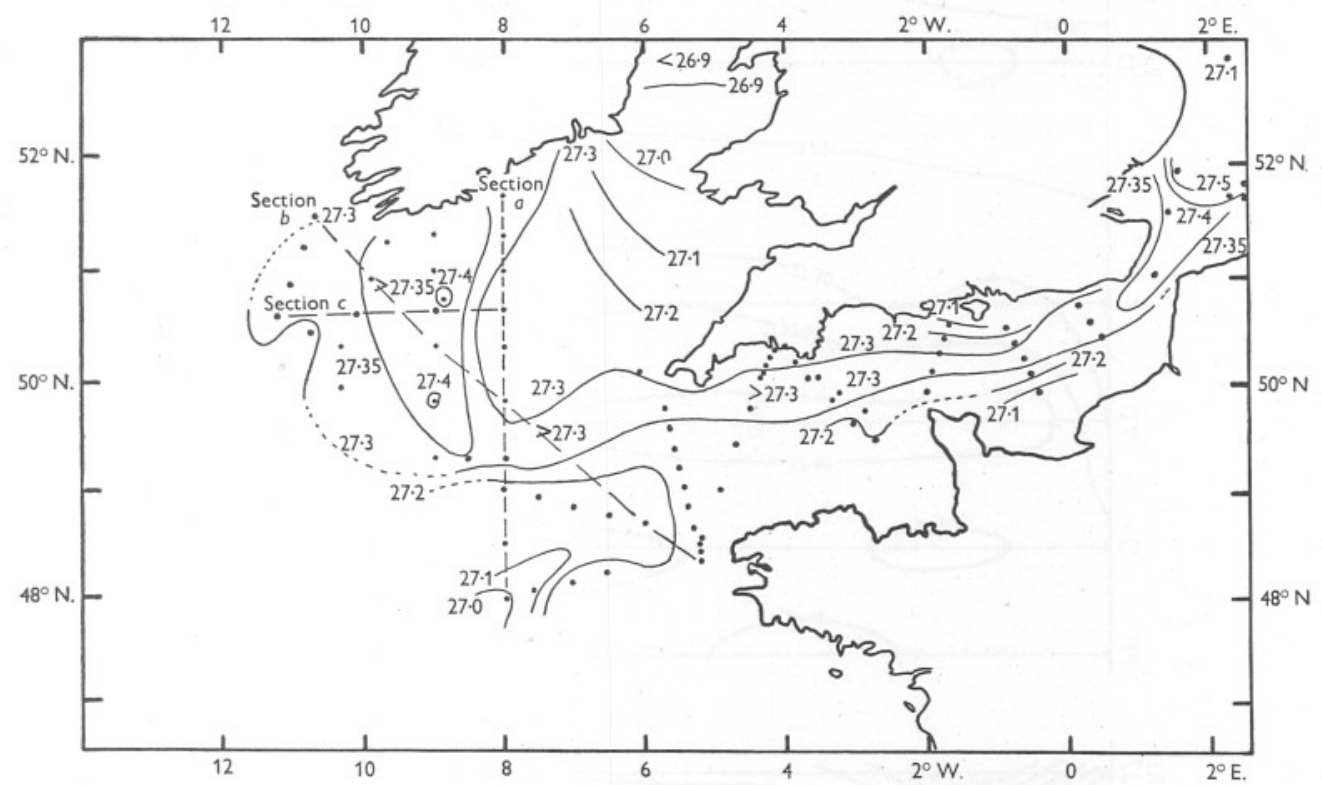

Fig. 7. Distribution of density of surface water between $I_{5}$ and 20 February 1927 . Also lines of three sections, vertical profiles along which are shown in Fig. 8. Profile $a$ along section $a$ ( $8^{\circ} \mathrm{W}$. long.); profile $b$ along section $b$ (north-west to south-east); profile $c$ along section $c$ (approx. $50^{\circ} 40^{\prime}$ N. lat.).

heavy enough to cascade and backed up by yet more heavy water in the English Channel.

The only observations over the edge of the slope were at the Irish station SS ( $50^{\circ} 34^{\prime}$ N., $\mathrm{II}^{\circ} \mathrm{I} 7^{\prime}$ W.) which was worked in August 1926 and February 1927. In August density increased downwards from $\sigma_{t} 27 \cdot 0 \mathrm{I}$ at $60 \mathrm{~m}$. to $27 \cdot 32$ at $400 \mathrm{~m}$. and 27.40 at $600 \mathrm{~m}$. The ocean there was prepared to receive water of density $\sigma_{t} 27 \cdot 32$ down to $400 \mathrm{~m}$. By February such water $\left(\sigma_{t} 27 \cdot 33\right.$, 10.52I0. $67^{\circ} \mathrm{C}$., $35.59-35.6 \mathrm{I} \%$ salinity) had arrived between the surface and $400 \mathrm{~m}$. It is the thesis of this paper that it had arrived by cascading. 

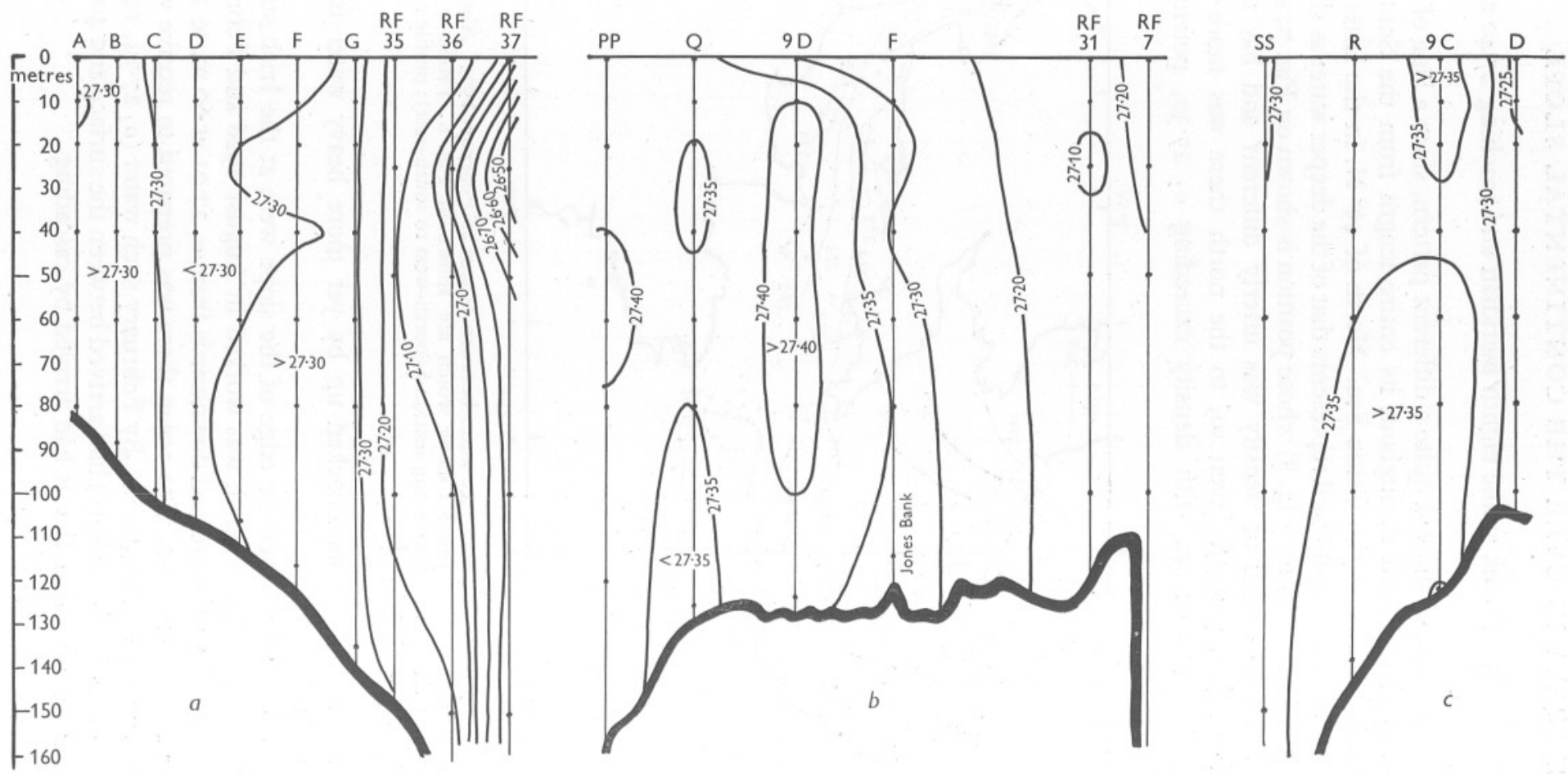

Fig. 8. Vertical profiles of density $\sigma_{t}$ along the three sections shown on Fig. 7. 
This 1927 data will be used again (pp. 733-5) in an attempt to establish the course taken by cascade water.

\section{CASCADING IN THE WINTER OF I9I3-I4}

The evidence considered so far has shown that cascading could have happened; it has not shown that it did. The observations beyond the slope have been scanty and, in any event, assurance can never be based on salinity, temperature and density alone. The most convincing evidence was obtained by the Armauer Hansen in June I9I4, and to make best use of it requires knowledge of conditions in the preceding winter, I9I3-I4. The Irish observations were few; of the usual network only stations $\mathrm{P}$ and $\mathrm{Q}$ were worked, together with several stations in the Nymphe Bank area. Detailed examination of all the surface data, collected in February and March I9I4, by merchant vessels in the eastern North Atlantic and Celtic Sea, has shown that some are under a heavy cloud of suspicion. The results of certain vessels, however, are consistent and appear sound, and these show that the distribution of temperature, salinity and density in the Celtic Sea in early I9I4 was very similar to that in early I927. At the Irish station P ( $5 \mathrm{I}^{\circ} 14^{\prime} 30^{\prime \prime} \mathrm{N} ., 9^{\circ} 43^{\prime} \mathrm{W}$.) and at Q ( $50^{\circ} 56^{\prime} \mathrm{N} ., 9^{\circ} 56^{\prime} \mathrm{W}$.) the temperature, salinity and density of the water at various depths have been compared with the means which had been calculated from all the observations ever taken there in February; at both stations the I9I4 values agreed almost exactly with the mean. Moreover, in February I9I4, air temperatures at Scilly, Valencia and Guernsey did not differ significantly from the respective means over the I3 years, I92I-33. Both of these statements have been shown to be similarly true for 1927. Since in 1927 (Fig. 8) surface values gave a sufficient picture of conditions on the shelf down to the bottom, it is highly probable that the same was true in I9I4.

In February 19I4, the surface observations showed that most of the Celtic Sea away from the coasts was occupied by water having $\sigma_{t}$ exceeding 27.30; a section of I20 miles along $49^{\circ} 45^{\prime} \mathrm{N}$. latitude revealed no values of $\sigma_{t}$ less than $27 \cdot 40$. Such surface water was heavy enough to cascade, and evidently there was a great deal of it. Later two sets of observations were taken across the slope at the positions shown in Fig. 9 (sections $a$ and $b$ ). There was an Irish line (Bull. Hydr., I9I3-I4) at about $50^{\circ} 30^{\prime} \mathrm{N}$. on I4 May, the densities along which are shown in Fig. IO, and a line by the Armauer Hansen (HellandHansen \& Nansen, I927) at about $48^{\circ} \mathrm{N}$. on 5-6 June (Fig. II $a$ ). No water heavier than $\sigma_{t} 27.30$ was found along either at less than $550 \mathrm{~m}$., while water having density between $27 \cdot 30$ and $27 \cdot 40$ occupied the next $250 \mathrm{~m}$. interval. Thus the February shelf water with the same density limits, if it had cascaded, would by May-June have sunk to some depth between 600 and $850 \mathrm{~m}$. at station 6 and between 700 and $1000 \mathrm{~m}$. at station 7 .

For a number of years we have shown that the water of the Celtic Sea 


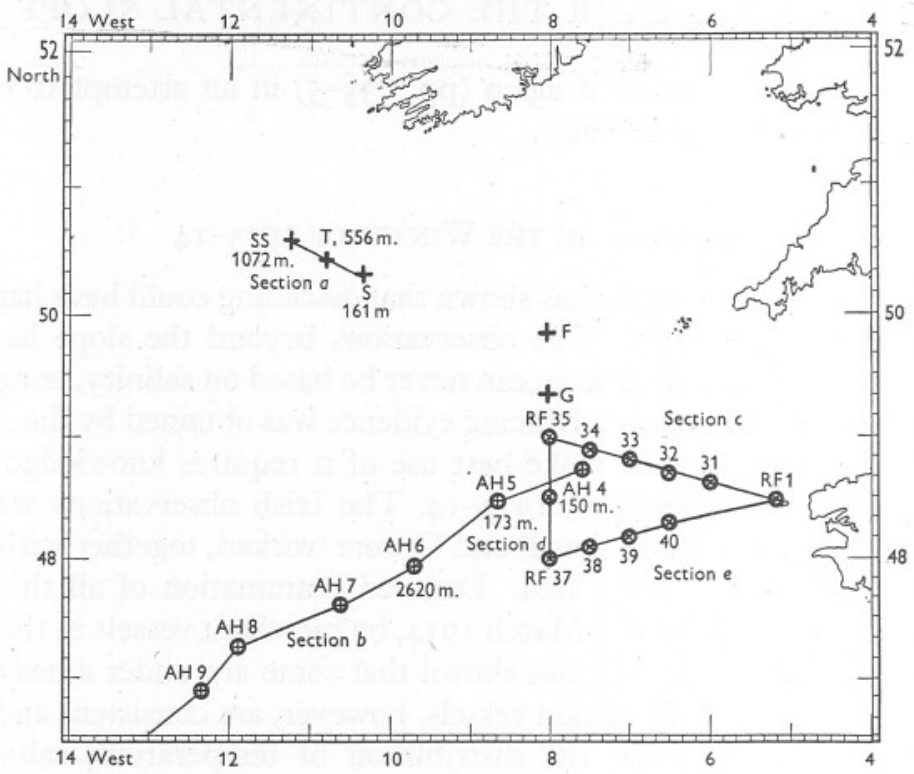

Fig 9. Chart of sections of which vertical profiles of density $\sigma_{t}$ are given in Figs. Io, I I $a$ and I3. Section $a$. Stations S-T-SS worked by the Irish Fisheries Service on I4 May I9I4 (see Fig. I0). Section $b$. Stations $4-9$ worked by the Norwegian research vessel Armauer Hansen on 5-6 June I9I4 (see Fig. II $a, b$ and $c$ ). Sections $c, d$ and $e$. Stations RF I and RF $3 \mathrm{I}-40$ worked round a triangle by a French gunboat on I5-I6 February I 927 (see Fig. $\mathrm{I}_{3} c, d$ and $e$ ).

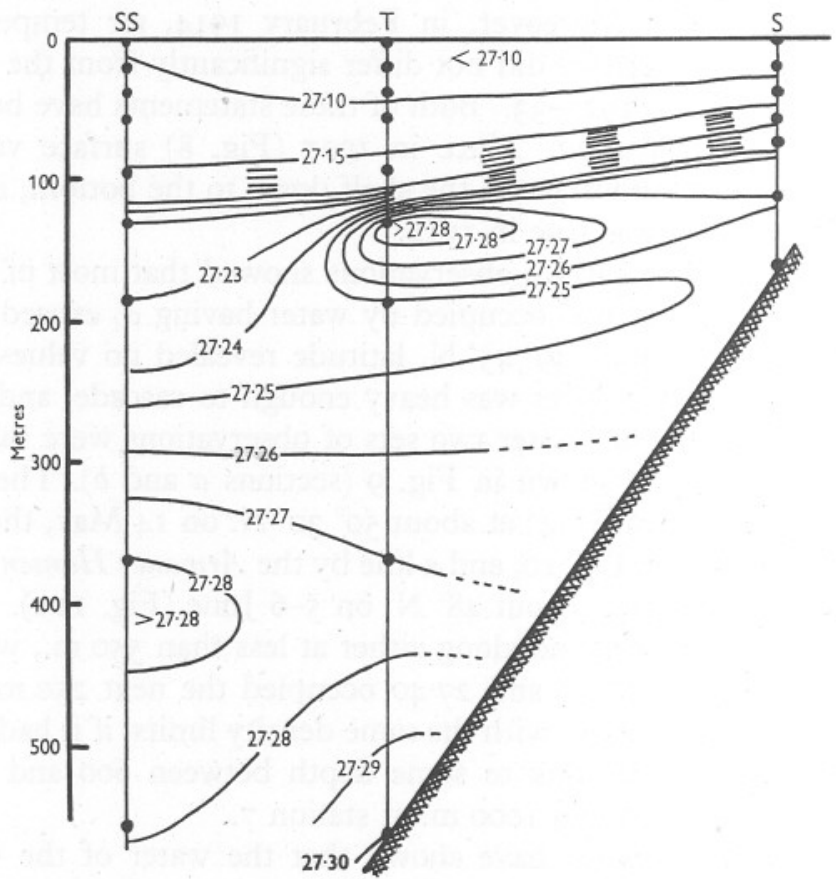

Fig. I0. Vertical profile of density on 14 May 1914, along section $a$ in Fig. 9. 
became heavy enough to cascade, but in only this one, I9I4, can we show that it actually did. What is needed is some measurement to demonstrate beyond doubt that the deep water, having $\sigma_{t} 27 \cdot 30-27 \cdot 40$, had been at the surface only shortly before. The oxygen determinations made by Gaarder (I927a) on board Armauer Hansen in the first week of June I9I4 achieve this (Fig. II $b$ ). His stations 8 and 9 represent conditions in the open Atlantic; since in the uppermost $40 \mathrm{~m}$. of water recent production by photosynthesis had exceeded consumption by respiration and breakdown, oxygen was supersaturated with respect to atmospheric pressure. From $40 \mathrm{~m}$. the oxygen content decreased steadily downwards to the minimum, $67-70 \%$ saturated, in the layers between 800 and $1000 \mathrm{~m}$. depth. Still farther westward this happened in North Atlantic Central water but here it occurred in water with a strong, warm, highly saline Mediterranean component. Nearer the slope in water $2620 \mathrm{~m}$. deep at station $6\left(47^{\circ} 57^{\prime} \mathrm{N} ., 9^{\circ} 42^{\prime} \mathrm{W}\right.$.), as shown in Fig. 9, a very different vertical distribution was present (Fig. II $b$ ). At 400,800 and $1200 \mathrm{~m}$. there were three strata of oxygen-rich water sandwiched between oxygen-depleted layers. This odd result, standing unsupported, would carry considerable doubt as to the soundness of the single oxygen determinations; but they are supported. At 800 and $\mathrm{I} 200 \mathrm{~m}$. the value of $\mathrm{pH}, 8 . \mathrm{I} 3$, was the same as at $\mathrm{I00} \mathrm{m}$. (Gaarder, I927b). Much later Buch, Harvey, Wattenberg \& Gripenberg (I932) and Buch (1933) evaluated the constants of the carbonic acid system in sea water so that it is now possible to evaluate partial pressures of carbon dioxide $p_{\mathrm{CO}_{2}}$ from determinations of $\mathrm{pH}$, salinity and temperature. It is necessary that $\mathrm{pH}$ should have been determined as described by Buch with due account of the several corrections needed. Consequently, it is unlikely that Gaarder's I9I4 measurements could be suitable for accurate computations of partial pressure of carbon dioxide, $p_{\mathrm{CO}_{2}}$, but none the less, they may be used for a rough and ready treatment sufficient for the present purpose. The results (Fig. II $c$ ) are striking, since a partial pressure, $3.4-3.5 \times \mathrm{IO}^{-4}$ atmospheres in water so deep as 800 and $\mathrm{I} 200 \mathrm{~m}$. is very unlikely in water which had been unventilated for any considerable time. There seems no choice but to believe that all the water at $800 \mathrm{~m}$. and most of that at $\mathrm{I} 200 \mathrm{~m}$., bracketing the depleted Mediterranean tongue between, had cascaded from the shelf 3 months or so earlier. It should also be noted that the salinity at 50-200, at 800 and at I200 m., 35.52-35:53\%, was constant; the waters agree in salinity, oxygen percentage saturation, $\mathrm{pH}$ and partial pressure of $\mathrm{CO}_{2}$ and differ only in temperature and density. There can be little doubt that they represent successive stages in the cascading of essentially the same body of shelf water as the temperature fell and rose again. At $400 \mathrm{~m}$., however, since the high oxygen content, $99 \%$ saturated, was associated with $\mathrm{pH} 8.05, \mathrm{p}_{\mathrm{CO}_{2}} 4.4 \times \mathrm{IO}^{-4}$ atmosphere and salinity $35.47^{\circ} \%$, no firm conclusion may be drawn.

Water cascading down the slope should inevitably acquire considerable momentum; if, therefore, heavy shelf water should have sunk to a level of 

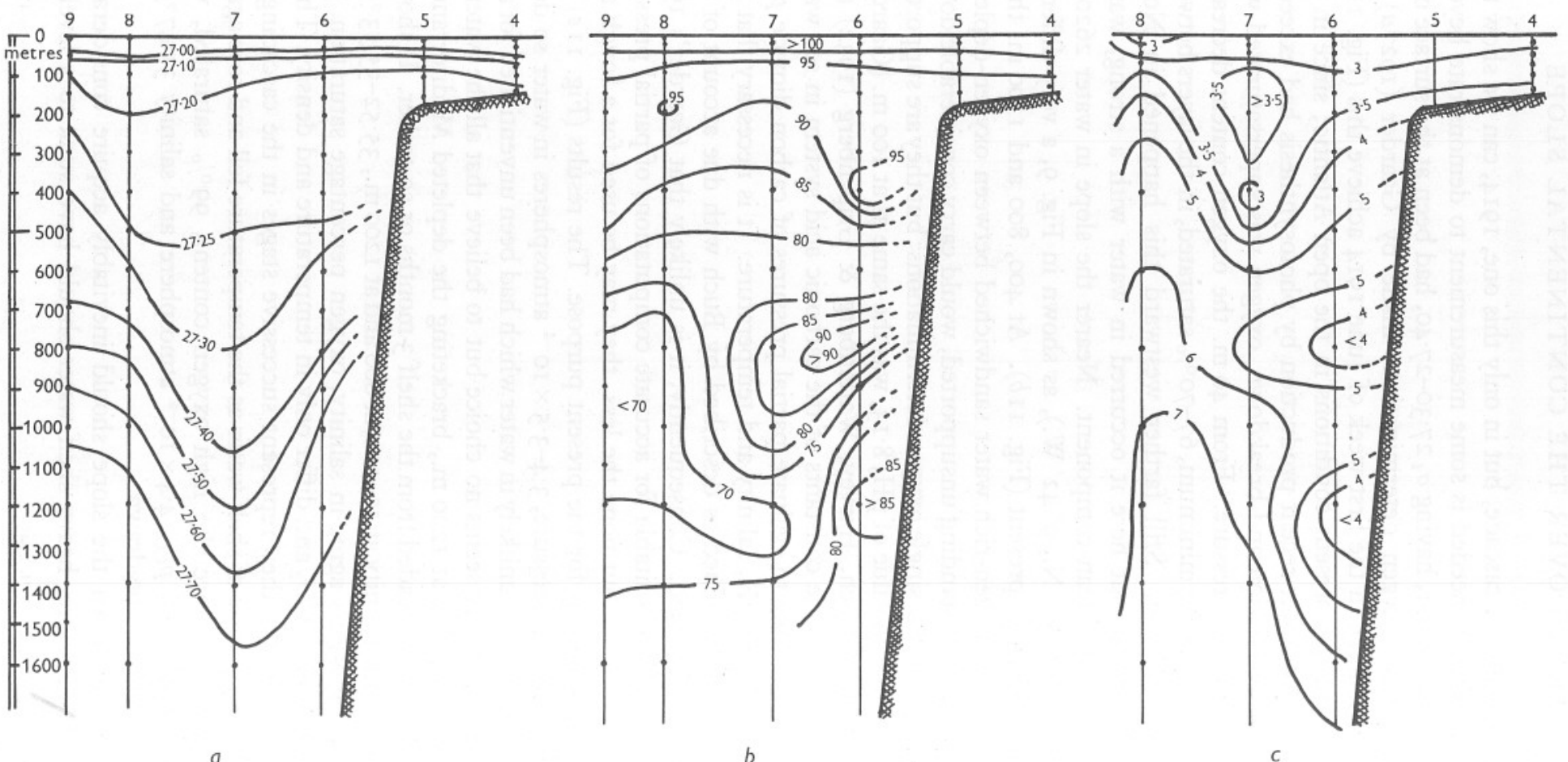

Fig. II. Profiles drawn from Armauer Hansen observations on 4-6 June I9I4 along section $b$ of Fig. 9. $a$, density $\sigma_{t}$; $b$, oxygen as percentage saturation value under atmospheric pressure; $c$, partial pressure of carbon dioxide, $p_{\mathrm{CO}_{2}}$, as atmospheres $\times \mathrm{I}^{-3}$, approximate only and computed without detailed corrections. 
density equal to its own, it might perhaps spread out at that level giving rise to lateral mixing along surfaces of equal $\sigma_{t}$. Such mixing takes place with minimum change in potential energy, the momentum or kinetic energy being used to overcome internal friction or to displace other bodies of water. If the cascade on the slope should become canalized within a submarine canyon, it would become a core which might possibly penetrate at its appropriate $\sigma_{t}$ level many miles into the ocean. This may have been the origin of the oxygenrich water, apparently a core, found on 7 June I9I4, at Armauer Hansen station Io $\left(46^{\circ} 26^{\prime} \mathrm{N}\right.$., I3 $3^{\circ} \mathrm{I} 4^{\prime}$ W.) at $600 \mathrm{~m}$. (94.5\% saturated) and at station II ( $46^{\circ} \mathrm{oo}^{\prime} \mathrm{N}$., I4 $4^{\circ} \mathrm{O} 3^{\prime} \mathrm{W}$.) at $800 \mathrm{~m}$. ( $86 \%$ saturated). These stations were respectively I 90 and 220 miles from the nearest part of the slope. Moreover, their densities were no greater than 27.26 and $27 \cdot 28$, and the temperatures and salinities were typical of western Celtic Sea water in January or April.

\section{The Course of the Cascade}

In general, the water near the slope has a higher salinity than that to the east at $9^{\circ} \mathrm{W}$., at $8^{\circ} \mathrm{W}$., and over the Nymphe Bank. When cascading happens it must necessarily draw colder but less saline water towards the west or southwest, so that during late winter and early spring, a decrease in salinity should mark the course of the water cascading from the Nymphe Bank.

In 1927 , fortunately, the Irish records were unusually complete, not only in February, but also in May, so that in that year it is possible to assess the changes in salinity over a wide area and so to chart the most probable course of the northern part of the cascade current. The two cruises were run between I7 and 20 February and between 6 and Io May; in Fig. I2 the stations worked on both are shown. It will be seen that the fall in salinity was especially marked on the eighth meridian between the coast and $5 \mathrm{I}^{\circ} 00^{\prime} \mathrm{N}$., at all stations worked on the ninth meridian, and at $5 \mathrm{I}^{\circ} \mathrm{I} 5^{\prime} \mathrm{N} ., 9^{\circ} 43^{\prime} \mathrm{W}$. This is precisely the distribution that the theory of cascading demands. It would seem that water cascading from the region of the Nymphe Bank set westsouth-west across the eighth meridian between the Labadie Bank and the coast of Co. Cork. Towards the ninth meridian it would seem to have divided; the northern branch hugged the coast and passed Mizen Head in a lane 20 miles wide, whilst the southern branch set south-west or south-south-west, with its axis crossing the ninth meridian at about $50^{\circ} 20^{\prime} \mathrm{N}$. and heading towards the Great Sole Bank area. It is suspected that its further course was controlled by the bottom configuration of that much dissected region, but direct observations are lacking. A similar fall in salinity took place in other, but not in all, years.

In the II weeks elapsing between the two 1927 cruises, the isohalines had advanced about 50 miles to the west or south-west. This gives an average speed of the cascading water at $9^{\circ} \mathrm{W}$. of about 0.5 miles per day. 
A submarine bank in the way of the cascade should impede it, a submarine valley should encourage it; consequently, the fall in salinity between February and May 1927 should have been least over a bank and greatest over a valley. This was the case: on the ninth meridian at station $9 \mathrm{C}$, on the edge of a bank, the fall in salinity was less by $0.03 \%$; and at station $9 \mathrm{D}$, at the head of a valley, it was greater by $0.02 \%$ o than a smoothed curve along the meridian

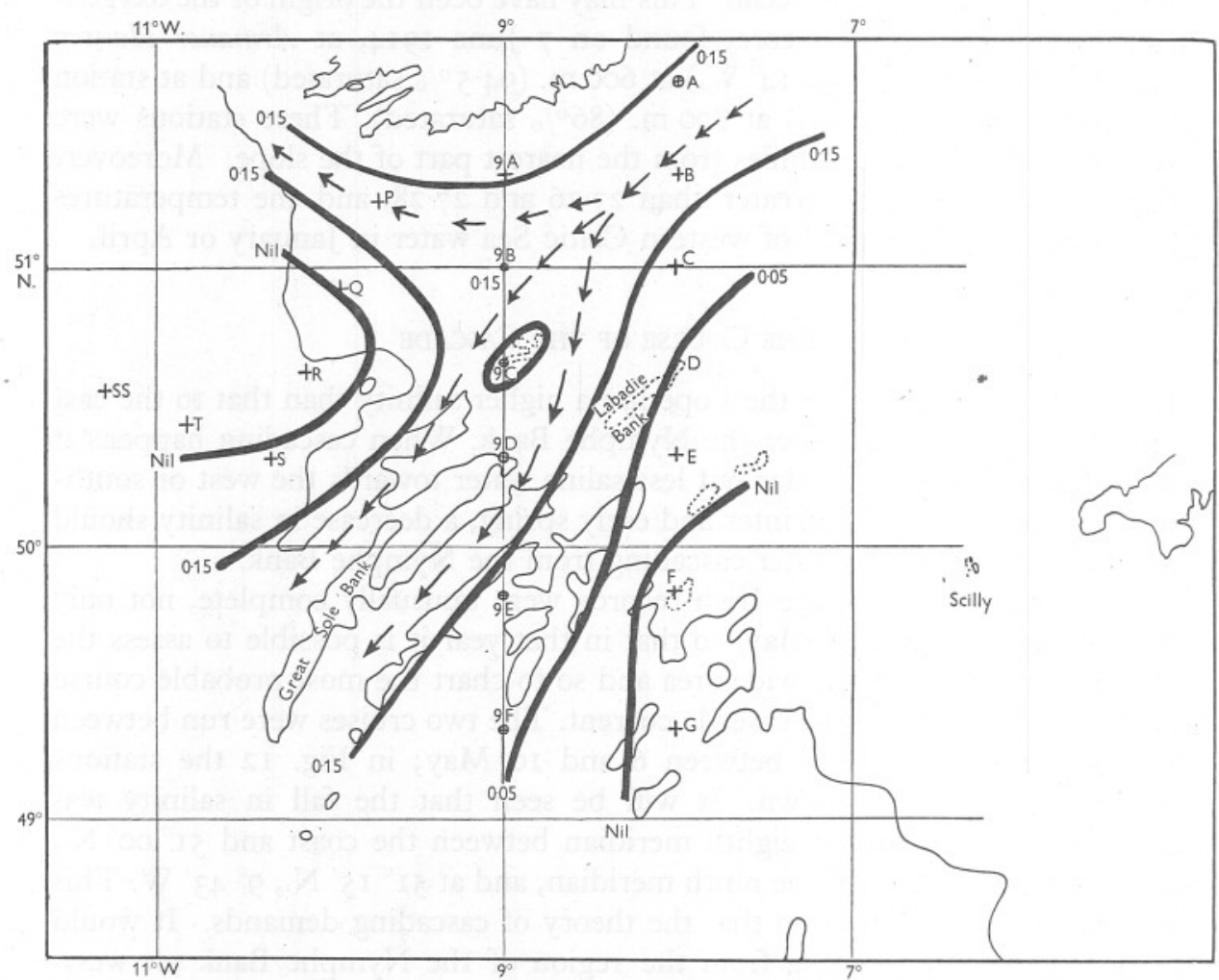

Fig. I2. Probable course in 1927 of cascading water over the shelf as indicated by the fall in salinity between I7-20 February and 6-10 May. The iso-lines represent decreases in salinity of $0.15,0.05$ and $0.00 \%$. The fall in salinity in the neighbourhood of the bank at Station $9 \mathrm{C}$, shown enclosed on the chart, was $0.13 \%$. The arrows show the most probable courses of the cascading water.

would have suggested, A similar deficiency of about $0.04 \%$ o shows up on the eighth meridian at station $\mathrm{D}$ at one end of the Labadie Bank. These results, slender though they are, combined with the considerations set out on pp. 722-4, have assisted in the extrapolation of Fig. I2 towards the Great Sole Bank.

It is not easy to assess the effect of the Corioli force, due to the earth's rotation, upon the cascade. It operates not on residuals, but on the currents which actually flow and include relatively large alternating tidal components. One can 
say only that the effect of the earth's rotation should be to encourage the cascade to hug the Irish coast and this the northern branch seemed to do.

Water from south-east of the Labadie Bank may also have contributed materially to the cascade. Since it was warmer but more saline, its course cannot be followed by these devices.

\section{COMPENSATION WATER}

The theory of cascading requires that loss of heavy water over the slope shall be made good by an inflow somewhere or other. Five sources of such compensation water may be considered:

(a) From the north-eastern Atlantic via the North Channel and the Irish Sea.

(b) From the North Sea via the Straits of Dover.

(c) By upwelling at a restricted part of the slope of the Celtic Sea.

(d) By an influx of saline but relatively warm and light Atlantic oceanic surface water.

(e) By an influx of coastal water from the French Biscayan shores.

(a) According to Proudman (I946, p. 59I) the mean current through the Irish Sea is from south to north, entering through the St George's Channel and leaving through the North Channel. In February 1927, water having density $\left(\sigma_{t}\right) 26 \cdot 7$ lay right across the Irish Sea from Holyhead to Kingstown, so that then the Irish Sea could have made no contribution to the cascade. It is unlikely that it ever does.

(b) The flow of water through the Straits of Dover has been very fully investigated at the Varne Lightvessel by Carruthers (1935). The mean flow of water in the nine Februaries of $1927-35$ was $I \cdot 9$ sea miles per lunar day towards $\mathrm{N} . \mathrm{I}^{\circ} \mathrm{W}$. true. In all other months the flow was directed to between $\mathrm{N}$. $14^{\circ} \mathrm{E}$. and N. $33^{\circ}$ E., whilst the strength ranged from 2.6 to 4.1 miles per lunar day. In February there is evidently strong westing and diminution of the 'normal' flow. Although this is precisely the effect which one would expect cascading from the Celtic Sea to have on the Straits of Dover current at the Varne, little confidence can be placed in the correlation. Following winds play a large part in impelling water towards the north-east through the Straits of Dover, and it so happens that February has been the month with least favourable winds. Again, March, which should be a month of strong cascading in the Celtic Sea, shows a set of average strength (3.0 miles per lunar day). Possibly more revealing is the average direction of the current, arranged in Table I, according to direction, by months for the 8 years, June I926-May 1934 .

Apart from September, which is irregular, the months with a set between N. $9^{\circ} \mathrm{W}$. and N. $18^{\circ} \mathrm{E}$. were those when some measure of cascading might have been expected, those with a set between N. $22^{\circ}$ E. and N. $35^{\circ}$ E. were months when cascading should not have occurred. 


\section{TABLE I}

Average Direction of Current at the Varne Lightvessel, Straits of DOVER, ARRANGED BY MONTHS, FOR THE 8 YEARS, JUNE I926 TO MAY I934

$\begin{array}{llllll}\text { February } & \text { N. } 9^{\circ} \mathrm{W} . & \text { July } & \text { N. } 22^{\circ} \mathrm{E} . & \text { October } & \text { N. } 26^{\circ} \mathrm{E} . \\ \text { May } & \text { N. } 11^{\circ} \mathrm{E} . & \text { August } & \text { N. } 22^{\circ} \mathrm{E} . & \begin{array}{l}\text { December } \\ \text { N. } 26^{\circ} \mathrm{E} .\end{array} \\ \begin{array}{l}\text { September } \\ \text { Npril }\end{array} & \text { N. } 3^{\circ} \mathrm{E} . & & & \text { January } & \text { N. } 34^{\circ} \mathrm{E} . \\ \text { June } & \text { N. } 15^{\circ} \mathrm{E} . & & & \text { November } & \text { N. } 35^{\circ} \mathrm{E} \text {. } \\ \text { March } & \text { N. } 17^{\circ} \mathrm{E} \text {. } & & & & \end{array}$

One is entitled to ask whether the backing of the current by $43^{\circ}$ between January at the end of the Table and February at the beginning is brought about in some measure by initiation of cascading from the Celtic Sea.

This possibility is supported by the distribution of density between I4 and 20 February 1927 (Fig. 7); for then a continuous line of water heavy enough to cascade $\left(\sigma_{t}>27.30\right)$ connected the Southern Bight through the English Channel with the Celtic Sea. Some compensation water for the Celtic Sea cascade could have been recruited along this lane.

A coincidence which may not have been due to chance should be noted. In his first report on current measurements at the Varne Lightvessel, Carruthers (1928) discussed at length the strongest set of the current towards the French coast, as assessed between 24 June I926 and 8 January I928. This set of 6.I miles per day towards S. 8I ${ }^{\circ}$ E. occurred between I6 and I9 February I927 during light local winds. Although not a reversal of the current it was a marked departure from normal. It would seem to reflect the pulse of the Celtic Sea cascade, transmitted along the Channel and revealed at the Varne in the absence of the currents, due to prevailing winds, which often completely obscure it.

Again, the strongest south-westerly set, $\mathrm{I} 2.9$ miles per day towards $\mathrm{S} .5 \mathrm{I}^{\circ} \mathrm{W}$., reported in Carruthers's second paper (I935), occurred in the cold winter of I930- on 7-IO February-when we have reason to believe that the Celtic Sea cascade was very strongly developed (pp. 743-4).

It is, therefore, possible that cascading from the Celtic Sea in February and March may provide one, but only one, of the forces which control currents in the Straits of Dover. Its effect may be to oppose, but seldom to cancel, the forces which tend most often to drive water from the Channel into the Southern Bight. The amount of compensation water from this source is probably small.

(c) Strong persistent easterly or north-easterly winds, blowing surface water from the shelf over the ocean, should here create the situation recognized the world over as favourable to upwelling of deeper nutrient-rich ocean water from several hundred metres. In winter such winds are cold winds which also favour cascading. Much of the slope west of the Celtic Sea should then be blanketed with a poorly stratified water which has recently cascaded. Upwelling of this, even if it should happen, would merely restore the status quo.

It is suspected but not proved (Cooper, I947) that internal waves in stratified 
deep oceanic water approaching the slope may run up it like a surface wave up a beach, so introducing nutrient-rich waters to higher levels. If a weakly stratified blanket of cascaded water lies between the stratified ocean water and the slope, the energy of the waves should be absorbed by the blanket and fail to reach the slope. Upwelling due to internal waves should therefore occur, never in winter and early spring, but perhaps in summer and autumn. Simultaneous cascading and upwelling seem to be incompatible. Unless very definite evidence can be found, it would seem that compensation, by upwelling, of water lost by cascading is very unlikely.

( $d$ and $e$ ) It would seem, therefore, that the main compensation for water lost by cascading should be provided by surface oceanic or Biscayan water entering the Celtic Sea from the south-west. Such intrusion of oceanic water frequently occurs and has been called by Le Danois (1938, p. I50) in French a 'transgression' and in English an 'expansion'. He defines a transgression as 'un mouvement périodique, d'amplitude variée, des eaux atlantiques d'origine tropicale, déterminant un empiètement momentané de ces eaux sur les eaux d'origine polaire et sur les eaux continentales. Les eaux de la masse transgressive ont toujours une salinité supérieure à $35 \%$ \% '. This concept has been strongly attacked by von Schubert (1935), although it may apply on occasion. None the less, on the theory here presented, in February and March cascading provides the primary driving force in the circulation of the Celtic Sea and the intrusion of Biscayan or oceanic water is the necessary consequence.

The inflow of very warm and saline ( $14^{\circ}$ C., $35.43 \%$ salinity) water in mid-February 1927 at about $48^{\circ} \mathrm{N}$., $8^{\circ} \mathrm{W}$. has already been described by Le Danois (1929), who hailed it as 'un phénomène de transgression très net et d'une grande intensité'. He figured the distribution of salinity and temperature but not that of density. Unfortunately, the French observations of temperature reported in the 'Bulletin Atlantique' for 1927 scarcely meet modern requirements, since they were printed either as whole numbers, e.g. $10^{\circ}$, or to one decimal place which was never a cypher. Statistical examination suggests that they may not be accurate to better than $\pm 0.3^{\circ} \mathrm{C}$. equivalent to an uncertainty in $\sigma_{t}$ of about \pm 0.05 . This numerical uncertainty, combined with the apparently fantastic distribution of density which they revealed, has led to their being regarded with reserve. Now they dovetail with the other data here considered to give a credible but still remarkable account. It is unfortunate that the clifflike break in density occurred in the narrow zone between the Irish and the French observations and could have been produced by a systematic error in either. The Irish records through the years include some evident misprints, but otherwise very extensive work on them has left little doubt as to their essential accuracy. The French records, as has been said, have not inspired confidence. It is of importance, therefore, that surface densities at three positions near Ushant worked by three different ships within five days are concordant. Consequently, it is not unreasonable to accept the whole of the French 
observations of temperature in 1927 within the limits of accuracy suggested above.

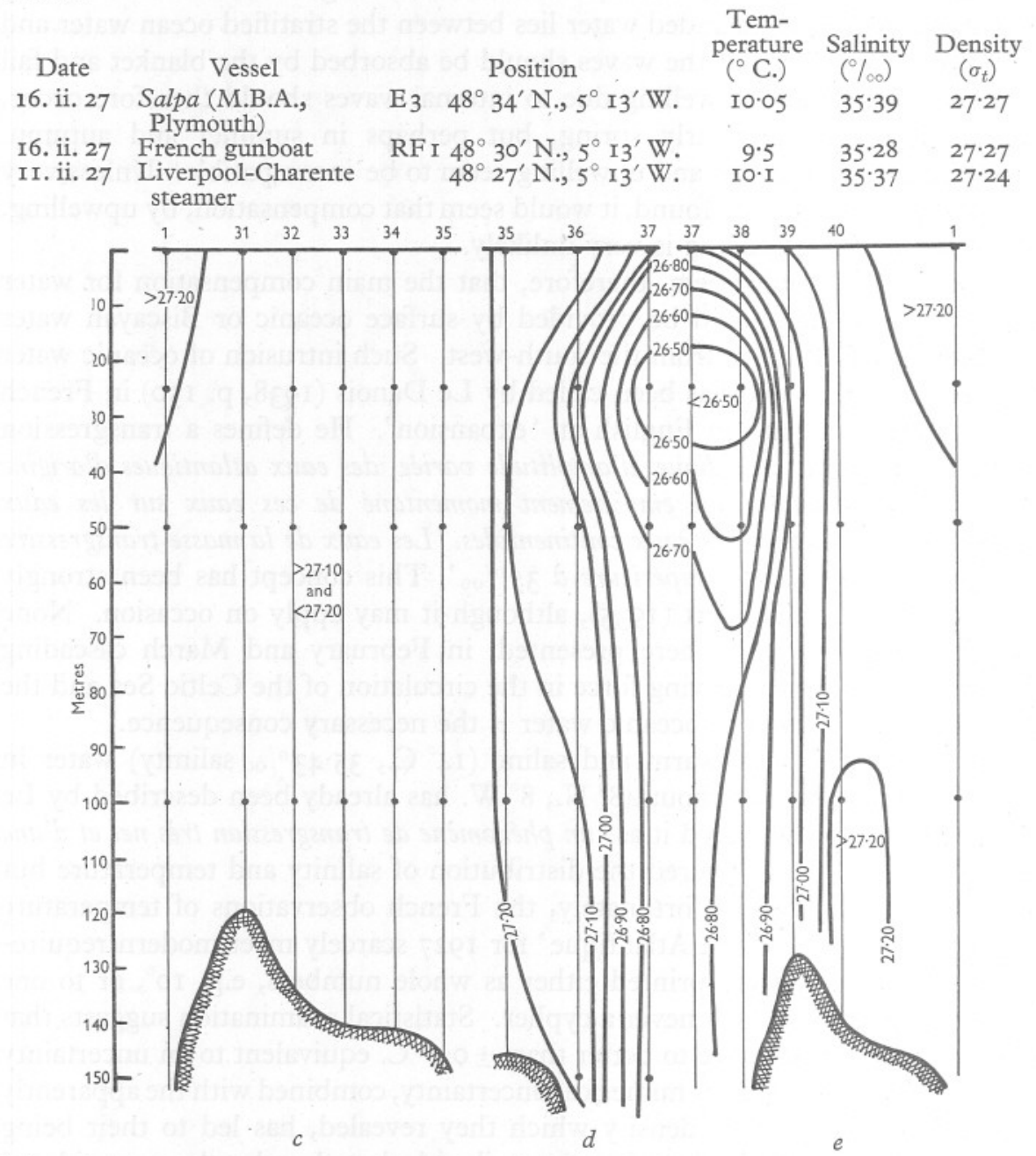

Fig. 13. Three vertical sections of density, $c, d$, and $e$, forming a triangle west of Ushant worked by a French gunboat on I5-I6 February I927. Positions are given in Fig. 9. Section $d$, Stations $35-37$ also forms part of Fig. $8 a$.

Three vertical sections (Fig. I3), one along the eighth meridian between 48 and $49^{\circ} \mathrm{N}$. and the other two completing a triangle to a point near Ushant (as shown on Fig. 9), illustrate the nature of the intrusion: an invaginated core or current about 30 miles wide and about 50 metres thick, sheathed on all sides by denser water. The most spectacular feature was the overlay or apron of surface water $0.5 \sigma_{t}$-unit heavier than the water at $25 \mathrm{~m}$. Considered as a problem in statics, such a distribution was impossible, for it should have been 
destroyed by vertical mixing in a very short time. It could have persisted only in a strongly dynamic system; the core of water of density $\left(\sigma_{t}\right) 26 \cdot 5$, driving east-north-east through the position $48^{\circ} \mathrm{N} ., 7^{\circ} 45^{\prime} \mathrm{W}$. must have been moving very fast towards the 30-mile-wide gap between the Shamrock Knoll and Parson's Bank. This seems to be another example of how bottom configuration may control currents.

At first sight the overlay of colder water having density 27.0 might seem to have arrived on the scene as a rapid surface drift driven over the main current by northerly or north-easterly winds. This could not have happened since the Daily Weather Reports show that no such winds blew. Alternatively, one may ask whether surface cooling of the warm intrusion could have been brought about quicker than the cooled water could be carried downwards. The air temperature over the northern Celtic Sea, taken as the mean of all observations between 6 February (oI00 hr.) and I4 February (I800 hr.) at Valencia, Roches Point (Cork Harbour), St Ann's Head (Pembroke) and Scilly was $6.3^{\circ} \mathrm{C}$. To the southward, air temperatures are in general higher, but on that occasion they were unlikely to have been so; although temperatures over inland Britain were much lower than over the Celtic Sea, those over the whole of France were lower still, being continuously below freezing-point from 8 to $\mathrm{I} 3$ February (Synoptic Charts to Daily Weather Reports). Winds blowing from the south-east over France should have been even colder than those from the north-east over Great Britain,

The entering oceanic water, warmer than $14^{\circ} \mathrm{C}$., was therefore exposed to air at least $8^{\circ} \mathrm{C}$. colder, a situation inevitably leading to warming of the air and surface cooling of the water. The warming of the cold continental air as it passed over the Celtic Sea shows up very clearly on the synoptic charts. The open question is: could isohaline water $2.5^{\circ} \mathrm{C}$. colder, due to rapid atmospheric surface cooling, and more than $0.5 \sigma_{t}$-unit heavier than the water beneath have persisted long enough to be observed? Even when wide allowance is made for the nature of the observations, there remains little doubt that it did. If this is accepted, then the core of warm light water at $25-50 \mathrm{~m}$., to have remained recognizable, would need to have moved very fast indeed. So far, there has been no opportunity to clothe this qualitative model in quantitative dress.

It is suggested that the invaginated current or core of warm water had been sucked in at a point of weakness over the slope, as into a void, to compensate water lost from the shelf by cascading. Such a compensation current may be expected on occasion to be narrow, fast and well defined. By contrast, a 'transgression' due to forces at work in the open ocean, and pressing warm water into the Celtic Sea against the inertia of the water already there would seem likely to create not such a core but rather a phalanx of water advancing slowly and relentlessly on a wide front.

On this occasion the balance of evidence is considered to lie heavily against a 'transgression' due to oceanic causes and in favour of a compensation 
current, called into existence and demanded by earlier and simultaneous cascading south-west of Ireland.

Productivity of the Celtic Sea and English Channel will be much affected by whether this oceanic or Biscayan water, entering to compensate the cascaded shelf water, has a greater, similar, or less content of nutrients. There are no nutrient analyses of Atlantic surface water at midwinter when the total stock may be assessed. At mid-January 1947 in the English Channel north of Brittany an extensive patch of warm (II $\left.\cdot 5^{\circ} \mathrm{C}\right)$, saline $(35 \cdot 39-35 \cdot 46 \%$ ) water was found, which had evidently entered recently either from Biscayan coastal regions or from the Atlantic to the south-west. Its phosphate content was very low, $0.38-0.40 \mathrm{mg}$.-atom $/ \mathrm{m}^{3}{ }^{3}$, less than two-thirds of that in the Celtic Sea at the same time. Although this may not have been compensation water in the sense considered here, none the less, it may indicate the nature of the change in nutrient balance which cascading brings about. The result suggests one line which future investigation should take.

\section{CASCADING ELSEWHERE}

The principle of cascading, i.e. winter cooling over relatively shallow banks or shelves in temperate latitudes to form water heavier than that in the neighbouring ocean at a greater depth, may apply widely. The Celtic Sea faces the Atlantic Ocean to the south and west, and is bordered by land and the shallowing Irish Sea to the north, and by the Bristol and English Channels to the east; its exposure to the continental slope and the ocean has a strong southerly component. In the northern and north-easterly parts of the Sea, water in winter will be most strongly cooled because it is shallower and always it will tend to be colder because it is farther from the equator than the water to the south. The two effects reinforce one another, so that cascading is favoured. In general, it is in border seas facing the equator that cascading is most likely to develop strongly.

In a sea, such as the North Sea, which faces towards the Pole, the two effects oppose one another so that cascading is much less likely to develop. Off the Atlantic Coast of North America the cold, low-salinity Labrador current introduces a complicating factor of great magnitude. In the neighbourhood of the Falkland Islands results obtained by the Meteor (Wattenberg, I933, and other relevant Meteor reports), in no way conflict with extensive cascading occurring there, but no definite conclusions can be drawn. At first view, the shelf around the Cape of Good Hope seemed a likely place for cascading, in spite of its poleward exposure, but examination of the Meteor and Discovery Station Lists shows that cascading does not take place; the inflow of the warm water in the Agulhas and Benguela currents far more than compensates winter cooling. The writers know of no other data for seas bordering the Atlantic where cascading might occur. In the eastern basin of the Mediterranean, 
Nielsen (I9I2, p. I42) recognized that the temperature of the deep water is determined by the inflow of colder masses of water from the Aegean Sea, and the Adriatic. This is nothing but a statement of cascading from two seas which face the equator.

\section{A Possible Apron of Surface Water beyond the SLOPE Rich IN ZooplankTON}

Let us reconsider Fig. 2. As the water moves from A to B it should carry with it its content of plankton. Furthermore, when at $\mathrm{C}$ it cascades over the slope those plankton organisms, lacking the power to swim, should be carried down. Neritic species should be found in the cascade water, perhaps at a considerable distance from the slope. It should be possible from amongst them to establish biological indicators by means of which cascade water may be recognized.

Plankton animals able to swim, especially those which undertake diurnal vertical migrations towards the surface, would swim up from the cascade into the overlying apron of warmer more oceanic water. In general, this apron would not be moving in the direction of the cascade away from the shelf, so that the cascade may be considered as flowing under it. Animals and plants unable to leave the cascade will be carried on and down; vertical migrants, whilst in the apron above, will not. Vertical migration should therefore tend to concentrate the more vigorous zooplankton from the cascade into a narrow stationary zone in the more oceanic water which would not normally provide their habitat and in which they might not be expected.

A characteristic of this zooplankton community should be the high proportion of vigorous shelf species known to undertake vertical migrations, and the scarcity amounting, perhaps, to complete absence, of shelf zooplankton with only weak powers of swimming and of shelf phytoplankton which should remain in the cascaded water.

In the absence of cascading, plant food will be available in quantity only in the illuminated layers; in contrast, cascading over the slope should each day carry down below the illuminated zone a supply of plants and of the herbivores which have recently fed. This supply may be replenished each day. The vertical range within which vertical migrants can find relatively rich food supplies should therefore be extended during cascading into the region between, say, the 100 and $200 \mathrm{fm}$. contours. Such conditions may favour the production of zooplankton of the kind which the $2 \mathrm{~m}$. stramin ring net catches. Moreover, these concentrations of zooplankton are likely to be sought out by pelagic fish.

The above picture should apply where the cascade flows over a smooth slope. If, however, the slope should be dissected by strongly developed submarine valleys or canyons, an even more strongly differentiated distribution 
might result. If such a valley should cut back into the shelf, it would seem that it could act as a gutter into which the heavy cooled water might tend to collect. Sample models should show whether this conception is, in fact, physically sound. If the gradient of the floor of the valleys should be steeper than that of the shelf, the rate of descent of the cascade should be accelerated, resulting in a concentration of vigorous zooplankton in a restricted zone above the valley at the expense of neighbouring undissected sections of the slope. The richest regions of all in winter may therefore lie above submarine valleys or 'canyons' in the slope where such exist.

The economic conclusion from this line of reasoning is that in the apron of more oceanic water overlying the cascade above the edge of the continental slope, pelagic fish are likely to find concentrations of food organisms greater than anything to be found on the continental shelf. They may provide a rich drift net fishery for vessels able to stand up to the weather.

The whole of this picture applies only when cascading is proceeding strongly, say in February and March, and not then in every year. It is suspected that in those months cascading provides one of the dominant driving forces of the water circulation in the whole of the Celtic Sea, and may have a powerful effect on the life patterns and rhythms of all animals living there. With the cessation of cascading, this concentration of planktonic food organisms and pelagic fish should tend to break up.

\section{THE TRANSPORT OF IRON}

Other investigations (Cooper, I948) have shown that the stock of iron in the sea water of the Celtic Sea tends to become concentrated in particles suspended in the bottom-most layers. A cascading bottom current of the type described here should have a powerful tendency to strip the stock of iron from the Celtic Sea, and to carry it over the slope into the ocean abyss from which much of it may never return. Although soluble nutrients may be made good by upwelling somewhere at some season or other, it is not easy to see how the stock of iron, mostly particulate, can be replaced in this way. Indeed, there may be no cycle of iron unless a geological time scale is used; plants and animals over the shelf may have to rest content with a supply of iron on slow but steady one-way passage from rivers to the ocean bed.

\section{REDISTRIBUTION OF NUTRIENTS}

Nutrients carried over the slope in cascading water would be lost from the shelf. Lack of balance between loss and replenishment may underlie the large variations in the nutrient resources in the English Channel in different years.

It may be profitable to discuss the likely fate of nutrients in the Celtic Sea at the end of this cascading period. As the surface waters warm up in spring 
they will become too light to cascade, although the underlying unheated water would continue able to do so. A marked redistribution of the waters would then start, and should have a number of consequences.

One result of the vernal phytoplankton outburst is an increase in the amount of faeces and detrital matter containing nutrient elements. These particles tend to sink into deeper water, leading to an enrichment of this with nutrients at the expense of the upper illuminated layers, a cumulative process. When this happens in an enclosed area, the autumn overturn restores the original situation and, in the course of the year, there is no loss. But when this deeper, enriched water is moving towards the west or south-west under the influence of the cascade while the warmed surface water is relatively stationary, a redistribution of nutrients should come about. The deeper water would be carrying away a rich store of nutrients of which some would spill over the slope whilst some, at the end of cascading, should come to rest as a rich reservoir towards the edge of the shelf.

The surface water in the eastern and north-eastern area of the Celtic Sea would have been depleted. If, in that area, the water which compensates the lost deep water has an equal nutrient content, by the autumn the position will become restored. If, however, as the slender evidence would suggest, the compensation water is poorer in nutrients, an overall impoverishment in the eastern area will result. Whatever the effect may prove to be, it should be most marked in those years in which cascading of bottom water persists particularly late, say, into May. Near the slope a high concentration of nutrients would naturally always be attributed to upwelling; however, at the season when cascading is coming to an end, a high nutrient content there might equally well have resulted from redistribution on the shelf beneath the discontinuity layer. The two situations should be distinguishable by the distribution of density along sections from the shelf over the slope to the deep ocean. Upwelling should not occur when the distribution of density strongly favours cascading.

\section{SOME Applications}

In 1927 , the stage was set for cascading to occur, but only in I914 has it been possible to show beyond question that it did. This was due to the measurements of oxygen content and of $\mathrm{pH}$ made by Gaarder on board Armauer Hansen. In future studies of slope oceanography in this area, determinations of oxygen will be essential, for with their help bodies of water with similar salinities but very different histories may be distinguished.

Although in 1930 conditions were very favourable for cascading, owing to the north-easterly and easterly winds, the evidence was not presented on behalf of the theory of cascading. Now that that theory has been tested in other years, a debating point must be made. The strong cooling in the winter of I930, reinforced by favourable winds, should have driven an abnormally 
large amount of water off the shelf. This water would have had to have been replaced somewhere within the Celtic Sea by an abnormally large influx of some other water. About 9 months later in the English Channel near Plymouth the change-over occurred in the nature of the sea water which has had such far-reaching consequences. All we can now do is to note the coincidence; whether they were cause and effect we cannot yet say.

How often cascading occurs we do not know. The winter of 1948-49 has been exceptionally mild, the mildest since I92I. Fortunately, it was possible to work two stations on the eighth meridian on 9-10 March 1949, which have given a good idea of cascading potential then (Table II). The cascading

\begin{tabular}{|c|c|c|c|c|}
\hline & Position & $\begin{array}{l}\text { Temperature } \\
\left({ }^{\circ} \mathrm{C} .\right)\end{array}$ & $\underset{(\%)}{\text { Salinity }}$ & $\underset{\left(\sigma_{t}\right)}{\text { Density }}$ \\
\hline $50^{\circ} 36^{\prime}$ N., & $\begin{array}{c}8^{\circ} \mathrm{O}^{\prime} \text { W. Near Station D } \\
\text { on Labadie Bank }\end{array}$ & $9 \cdot 97-10.00$ & $35 \cdot 23-35 \cdot 24$ & $27 \cdot 15-27 \cdot 17$ \\
\hline $\begin{array}{l}49^{\circ} 50^{\prime} \mathrm{N} . \\
50^{\circ} 03^{\prime} \mathrm{N} .\end{array}$ & $\begin{array}{l}8^{\circ} 00^{\prime} \mathrm{W} . \text { Station F } \\
5^{\circ} 43^{\prime} \mathrm{W} . \text { Longships bearing } \\
3.5 \text { miles } 355^{\circ}\end{array}$ & $\begin{array}{c}10.28 \\
9.58-9.65\end{array}$ & $\begin{array}{l}35 \cdot 22-35 \cdot 23 \\
35 \cdot 2 I-35 \cdot 23\end{array}$ & $\begin{array}{l}27 \cdot 09-27 \cdot 10 \\
27 \cdot 19-27 \cdot 22\end{array}$ \\
\hline
\end{tabular}

potential of Celtic Sea water having density $\left(\sigma_{t}\right)$ around $27 \cdot 15$ is probably slight; there have been years in which it has been even less. It is clear that the tendency of Celtic Sea water to cascade, and for consequent incursion of Atlantic surface water in compensation, will vary greatly from year to year. Although it provides a theme fraught with possibilities in studies of the biological productivity of the whole area, its further examination has had to be deferred. So far, stress has been placed on cascading of shelf water to considerable depths over the slope, but it should be clear that at the beginning and end of the cascade the water of intermediate density will flow off only as a shallow subsurface flood. Consequently, when cascading has occurred, water which has acquired 'neritic' or coastal characteristics whilst on the shelf should stretch out into the Atlantic beyond the slope for many miles, with consequent effects on the character of the plankton living there.

Since an ultimate aim is to correlate the physical oceanography of the Celtic Sea with the distribution of plants and animals, attention should be drawnfor what it is worth, which may prove to be little-to a notable resemblance of the diagrams showing the probable course of the cascade in 1927 as deduced from the fall in salinity (Fig. I2) to Steven's diagram (I948, p. 525, fig. 5) illustrating the migrations of the mackerel at this season. In both diagrams there are bifurcating arrows south of the Irish coast about $8^{\circ}-8^{\circ} 30^{\prime} \mathrm{W}$., the one suggesting cold relatively brackish water drawn towards the cascades over the slope, the other mackerel migration routes. 


\section{The Effect upon Fisheries in SHaLlow Waters of AUTUMN COOLING OVER BANKS}

As a rider to the general thesis of this paper let us now consider a shallow flattopped submarine bank rising from a considerable depth on all sides (Fig. I4). From the basic argument (p. 72I), in cold weather a shallow bank of limited extent would seem always to be the site of convergence and descent, never of divergence and ascent.

The local divergences and convergences studied by Woodcock (1944) and others, were not the result of bottom topography and are quite different from the phenomenon here to be described.

On such a declivity plant cells are likely to be carried below the photosynthetic zone before they can have had time to divide and multiply. Phytoplankton should be sparse. None the less plankton, plant and animal, should be sucked into the convergence from a distance and then carried down the slope of the bank.

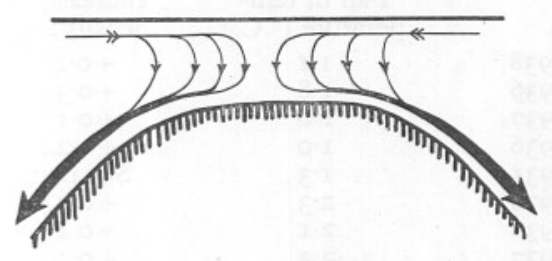

Fig. I4. Local cascading over a bank on a shelf

On such a declivity, demersal fish and filter-feeding sessile organisms should continuously be presented with a fresh supply of food. Such animals may tend to congregate on declivities in cold weather rather more than they do in warm. Again, there are animals which undertake the arduous process of reproduction in autumn and winter when the supply of food in the sea is sparse; is there any evidence that such animals seek declivities where they are exposed to cascading water?

This local form of cascading may arise during cold weather at any season of the year, but it should develop most strongly during the autumn when the rate of cooling of the water is at its greatest. Only then is it likely to occur on a scale sufficient to compete with the forces opposing its development, viz. wind drift, waves and tides.

One of the declivities where mackerel congregate in November and December is the Voyageur Bank in the Straits of Dover (Steven, 1949). Nearby lies the Varne Lightvessel from which very large numbers of surface hydrographical observations have been made. Those for the autumns of the 4 years, I935-38, have been examined. During October and November the average rate of cooling was about $0.07^{\circ} \mathrm{C}$. per day rising during December to $0.10^{\circ} \mathrm{C}$. per day; after Christmas, further cooling took place much more slowly and sporadically. 
Since the higher the temperature the greater the effect of a fall of $\mathrm{I}^{\circ} \mathrm{C}$. upon increase in density (Atkins, I925) the rates of increase in density in November and in December were about the same. Moreover, local cascading should have developed just as strongly in October. If, therefore, local cascading is the magnet which draws mackerel to the declivity in November and December, it ought to do so during October also.

Falls in temperature of the water at the Varne of more than $\mathrm{I}^{\circ} \mathrm{C}$. in 4 days, accompanied by increases in density $\left(\sigma_{t}\right)$ of more than 0.15 are as set out in Table III.

Table III. Occasions at the Varne Lightvessel in the Four Seasons (OCtOBER-MARCH) OF I935-36 TO I938-39, WHEN TEMPERATURE FELL BY MORE THAN I ${ }^{\circ}$ C. IN 4 DAYS AND DENSITY INCREASED BY MORE THAN $0.15 \sigma_{t}$ UNIT.

\begin{tabular}{|c|c|c|c|}
\hline Date & $\begin{array}{l}\text { Fall in tem- } \\
\text { perature }\left({ }^{\circ} \mathrm{C} .\right)\end{array}$ & $\begin{array}{l}\text { Increase in } \\
\text { density }\left(\sigma_{t}\right)\end{array}$ & $\begin{array}{l}\text { Fall in air } \\
\text { temperature at } \\
\text { or.00 hr. at } \\
\text { Lympne }\left({ }^{\circ} \mathrm{C} \text {. }\right)\end{array}$ \\
\hline 5-9 Nov. 1938 & $I \cdot I$ & $+0.2 I$ & See text \\
\hline 13-I7 Nov. I936 & $I \cdot 8$ & +0.33 & $7 \cdot 9$ \\
\hline I3-I7 Nov. I937 & $I \cdot O$ & +0.17 & 5 \\
\hline I-5 Dec. I936 & $I \cdot O$ & +0.24 & $6 \cdot 5$ \\
\hline 9-I3 Dec. I935 & $I \cdot 3$ & See text & See text \\
\hline I7-2I Dec. I938 & $2 \cdot 3$ & +0.44 ! & \\
\hline 2I-25 Dec. I938 & $2 \cdot I$ & +0.25 & 15.5 \\
\hline 25-29 Dec. I937 & $2 \cdot 3$ & +0.20 & $8 \cdot 3$ \\
\hline
\end{tabular}

The air temperatures at the near-by meteorological station at Lympne at or $\cdot 00 \mathrm{hr}$. for each period have been extracted from the Daily Weather Report. In early November 1938, it is clear that local air temperatures had little to do with the fall in sea temperature which must have been associated with horizontal currents. The period 9-I3 December 1935, has to be considered as part of the longer period, I-I3 December, during which the air temperature at Lympne at or.oo hr. was $6-\mathrm{II}^{\circ} \mathrm{C}$., colder than that of the sea at the Varne which was falling rapidly. Density increased by $0.33 \sigma_{t}$-unit over the whole period, but air and sea temperatures and density do not correspond in detail. On the other occasions a sharp fall in the temperature of the air accompanied that of the sea, and leaves no doubt that the one was the cause of the other. Local cascading should have been much favoured on these occasions. Most favourable of all should have been I4 and I5 November I936; I3, I4 and I5 November I937; I and 2 December I936; 2-I3 December I935; I8-26 December I938; and 25 and 26 December I937. If records are extant to show that landings of mackerel from the Voyageur Bank area were well above average on these occasions, the general thesis would be very strongly supported. Unfortunately, a negative result would not finally dispose of it since, if no mackerel were present in the area, they could not be caught either on declivities or anywhere else. 
The autumn of 1938 differed from the other three. The rate of cooling was greatest in October and December, and slight in November. On the present hypothesis, therefore, any mackerel present in the Straits of Dover should have congregated on the Voyageur and similar Banks in October, scattered in November and reassembled in December. Since this issue is evidently of direct importance to the fisherman it merits further direct observation.

\section{SUMMARY}

In the Celtic Sea, to the south of Ireland, water in some winters becomes sufficiently cooled and heavy to flow to the edge of the continental shelf and to run down the continental slope to a depth of several hundred metres. A theory of the phenomenon, termed 'cascading', has been developed. Three winters have been examined in detail.

In February I927 much water, heavy enough to cascade, was present in the Celtic Sea and also in the English Channel. A probable course and speed of the cascading water over the shelf has been established. Since there were few observations of salinity and temperature over or beyond the slope, and none of oxygen anywhere, the theory cannot be completely established on the basis of the 1927 observations, full though they were.

What is needed is some measurement to demonstrate beyond doubt that water, having density $\sigma_{\ell} 27^{*} 30-27 \cdot 40$, had been ventilated at the surface only shortly before. The measurements of oxygen content and $\mathrm{pH}$ made by Gaarder on board the Armauer Hansen in June I9I4 achieve this. The distribution of density on the shelf in the previous winter has been pieced together. There remains little doubt that water off the slope at 800 and $1200 \mathrm{~m}$. depth had cascaded shortly before. Direct observations, designed for the purpose, are now needed to clinch the argument.

Loss of water from the Celtic Sea by cascading requires that somewhere or other compensation water must enter. The Irish Sea appears to contribute neither to the cascade nor to the compensation water. The cascade may reduce the strength of the current through the Straits of Dover towards the North Sea, but seems seldom able to annul it. Little compensation water would seem to come that way. Since simultaneous cascading and upwelling over the slope seem incompatible, the only considerable sources of compensation water would seem to be the surface waters of the Atlantic Ocean and Bay of Biscay. A very strong inflow from the Atlantic into the southern Celtic Sea in February I927, previously considered to be a 'transgression', is here regarded as compensation water, the necessary consequence of cascading.

The inflow consisted of an invaginated core of warm, saline water sheathed on all sides by heavier water. The surface water was heavier by $0.5 \sigma_{t}$-unit than the water at $25 \mathrm{~m}$. The meteorological and dynamic meaning of this odd, very unstable distribution has been discussed. 
Although the tendency to cascade was strong in February I930, events in that year have not been adduced as evidence for cascading. Strong northeasterly and easterly winds could have driven water off the shelf without help from cascading. Winds and tendency to cascade, together, should none the less have brought about great loss of water from the northern Celtic Sea, and made necessary a large inflow of compensation water somewhere or other. Attention is drawn to the coincidence of this with changes in the nutrient salt regime in the western English Channel a few months later.

It is considered that the submarine banks and valleys of the Celtic Sea are likely to exert considerable control over the direction taken by currents initiated by cascading or by winds. A final conclusion demands more knowledge of bottom configuration and of the currents which actually flow, particularly in winter.

Theoretical argument suggests that during strong cascading an unusually high concentration of large vigorous carnivores may develop in the apron of more oceanic water overlying the cascade over and beyond the slope. This apron might possibly be the site of a rich pelagic fishery.

It is suggested that the stock of iron in the Celtic Sea may be on slow but steady one-way passage from rivers to the ocean bed.

Marked redistribution of nutrients may result, particularly from cascading of cold bottom water underlying surface water which has warmed up and been the site of production of plants and animals.

As a rider to the general thesis, local cascading over shallow flat-topped banks on the continental shelf during autumn cooling has been considered. Circumstances may then favour the concentration of fish over declivities.

\section{REFERENCES}

AtKINs, W. R. G. I925. On the thermal stratification of sea water and its importance for the algal plankton. Fourn. Mar. Biol. Assoc., Vol. I3, pp. 693-99.

Buch, K., Harvey, H. W., Wattenberg, H. \& Gripenberg, S., I932. Über das Kohlensäuresystem im Meerwasser. Conseil Int. Explor. Mer, Rapp. Proc. -verb., Vol. LXxix, pp. I-70.

Buch, K., 1933. Der Borsäuregehalt des Meerwassers und seine Bedeutung bei der Berechnung des Kohlensäuresystems im Meerwasser. Conseil Int. Explor. Mer, Rapp. Proc. -verb., Vol. Lxxxv, pp. 7I-5.

Bullard, E. C. \& Gaskell, F. F., I94I. Submarine seismic investigations. Proc. Roy. Soc. A, Vol. 177, pp. 476-99.

CARRUTHERS, J. N., I928. The flow of water through the Straits of Dover as gauged by continuous current meter observations at the Varne Lightvessel $\left(50^{\circ} 56^{\prime} \mathrm{N}\right.$., $\mathrm{I}^{\circ} \mathrm{I} 7^{\prime}$ E.). Fisheries Investigations, Ser. II, Vol. xI, pp. I-IO9.

- I935. The flow of water through the Straits of Dover. Part II. Fisheries Investigations, Ser. II, Vol. xIV, pp. I-67.

COOPER, L. H. N. I947. Internal waves and upwelling of oceanic water from middepths on to a Continental Shelf. Nature, Vol. 159, p. 579. 
COOPER, L. H. N., I948. The distribution of iron in the waters of the western English Channel. fourn. Mar. Biol. Assoc., Vol. 27, pp. 279-325.

Corbin, P. G., I942. The distribution of Arachnactis albida M. Sars in the Celtic Sea. fourn. Mar. Biol. Assoc., Vol. xxv, pp. 509-16.

DANOIS, E. LE, 1929. Rapport Atlantique 1927, remarques hydrologiques (Secteur Nord). Conseil Int. Explor. Mer, Rapp. Proc. -verb., Vol. Lv, pp. 29-49.

- 1938. L'Atlantique: Histoire et vie d'un Ocean, 291 pp. Paris: Albin Michel.

Deacon, G. E. R., I937. The hydrology of the Southern Ocean. Discovery Reports, Vol. xv, pp. I06-I7.

EkMAN, V. W., I905. On the influence of the earth's rotation on ocean currents. Arkiv. Mat. Astr. Fysik, Bd. 2, No. II, 52 pp.

— I923. Úber Horizontalzirkulation bei winderzeugten Meeresströmungen. Arkiv. Mat. Astr. Fysik, Bd. I7, No. II.

— 1927. Meeresströmungen. Handbuch physik. techn. Mechanik, Bd. 5, pp. I77206.

- 1932. Studien zur Dynamik der Meeresströmungen. Gerlands Beitr. Geophysik, Bd. 36 , pp. $385-438$.

Farrington, A., I945. The level of the ocean in glacial and late-glacial times. Proc. Roy. Irish Academy, Vol. L, pp. 237-43.

Flint, R. F., 1947. Glacial Geology and the Pleistocene Epoch, 589 pp. New York: John Wiley.

GAARDER, T., I927a. Die Sauerstoffverhältnisse im Östlichen Teil des Nordatlantischen Ozeans. Geofys. Publ., Oslo, Vol. rv, No. 3, 72 pp.

— I927b. Die Wasserstoffionenkonzentration des Meerwassers im östlichen Teil des Nordatlantischen Ozeans. Geofys. Publ., Oslo, Vol. Iv, No. 4, 23 pp.

Helland-Hansen, B. \& Nansen, F., 1927. The Eastern North Atlantic. Geofys. Publ., Oslo, Vol. Iv, No. 2, 76 pp.

IsELIN, C. O'D., I940. The necessity of a new approach to the study of the circulation on the continental shelf. Trans. Amer. Geophys. Union, pp. 347-8.

Matthews, D. J., I9I4. The salinity and temperature of the Irish Channel and the waters south of Ireland. Fisheries Ireland Sci. Invest., I9I3, Iv, 26 pp.

Nansen, F., I912. Das Bodenwasser und die Abkühlung des Meeres. Int. Rev. ges. Hydrobiol. Hydrog., Bd. v, pp. I-42.

Nansen, F., I913. The waters of the north-eastern North Atlantic. Int. Rev. ges. Hydrobiol. Hydrogr., Supplement to Bd. Iv, I39 pp.

Nielsen, J. N., I9I2. Hydrography of the Mediterranean and adjacent waters. Rep. Danish Oceanographical Exp. I908-10 to the Mediterranean and adjacent Seas. Vol. I, pp. 76-192.

Proudman, J., I946. On the salinity of the surface waters of the Irish Sea. Phil. Trans. Roy. Soc., Ser. A, Vol. 239, pp. 579-92.

SCHUBERT, O. von, 1935. Die Theorie der Transgressiononen von Le Danois und ihre Beziehung zum Golfstrom-Problem. Ann. Hydr. Marit. Meteorol. Jahrg. LXIII, pp. I40-3.

ShePARD, F. P., EMERY, K. O. \& LA Fond, E. C., I94I. Rip currents: a process of geological importance. Fourn. Geol., Vol. 49, pp. 337-69.

Steven, G. A., I948. Contributions to the biology of the mackerel, Scomber scombrus L.: mackerel migrations in the English Channel and Celtic Sea. Fourn. Mar. Biol. Assoc., Vol. xxvII, pp. 517-39.

1949. Contributions to the biology of the mackerel, Scomber scombrus, L. II. A study of the fishery in the south-west of England with special reference to spawning, feeding and 'fishermen's signs'. Fourn. Mar. Biol. Assoc., Vol. xxvIII, pp. $555-8 \mathrm{r}$. 
Sverdrup, H. U., Johnson, M. W. \& Fleming, R. H., I942. The Oceans, I087 pp. New York.

WATtenBerG, H., I933. Das chemische Beobachtungsmaterial und seine Gewinnung. Wiss. Ergebn. deutsch. atlantischen Exped. 'Meteor'. 1925-27. Bd. viII, and Beilage. Woodcock, A. H., I944. A theory of surface motion deduced from the wind-induced motion of the Physalia. Fourn. Mar. Research, Vol. v, pp. 196-205.

\section{APPENDIX}

\section{The Name 'Celtic SeA'}

This paper has been concerned with the 'sea area to the south of Ireland and off the western entrance to the English Channel', a cumbrous description which defies repetition. The accounts of previous biological and hydrographical investigations in the area have suffered from the lack of any concise name, while reference to different parts of the whole has been even more difficult. The name 'Western Approaches' is incomplete, and 'Chops of the Channel' too colloquial. The area is geographically, oceanographically and biologically a unity, and it is for this reason that a new name should be justified. The need was first recognized and met by E. W. L. Holt who, at a meeting of Irish, Scottish, English and French fishery experts held at Dublin in I92I, proposed the name 'Celtic Sea', after the Celtic lands of Brittany, Cornwall, Wales and Ireland, which border it. Holt seems never to have used the name in his publications, neither is there any record of its formal adoption or of a definition. Even so, his ideas were well formulated and known, as Le Danois (I938, p. 84) testifies. The term had attained currency in French writing, as in Le Danois' book, but none in English, until Corbin (1942) used it. Since 'Celtic Sea' is so concise and self-explanatory it has been used here but is felt to need definition as follows:

The Celtic Sea covers that part of the continental shelf of the Eastern North Atlantic Ocean bounded:

(a) On the east by the shortest line between the western point of the Island of Ushant (Ile d'Ouessant) and Lands End (Cornwall) and by the shortest line between Lands End and Ramsey Island, off St David's Head, Pembrokeshire.

(b) On the north by the shortest line from Ramsey Island to Carnsore Point, Co. Wexford, by the south coast of Ireland from Carnsore Point to Dursey Head, Co. Kerry, and by the shortest line from Dursey Head to the $200 \mathrm{~m}$. (or alternatively the $100 \mathrm{fm}$.) contour.

(c) On the west and south-west by the $200 \mathrm{~m}$. (or $100 \mathrm{fm}$.) contour.

(d) On the south by the shortest line from the western point of Ushant to the $200 \mathrm{~m}$. (or $100 \mathrm{fm}$.) line. 